\title{
Flavonoid Glycosides with a Triazole Moiety for Marine Antifouling Applications: Synthesis and Biological Activity Evaluation
}

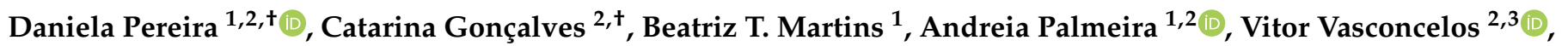

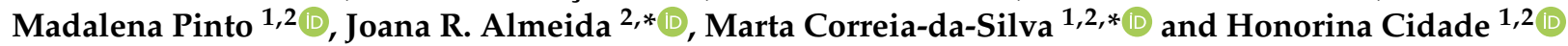 \\ 1 Laboratório de Química Orgânica e Farmacêutica, Departamento de Ciências Químicas, Faculdade de \\ Farmácia, Universidade do Porto, R. Jorge de Viterbo Ferreira 228, 4050-313 Porto, Portugal; \\ dmpereira@ff.up.pt (D.P.); beatriz.martins@itqb.unl.pt (B.T.M.); apalmeira@ff.up.pt (A.P.); \\ madalena@ff.up.pt (M.P.); hcidade@ff.up.pt (H.C.) \\ 2 CIIMAR-Centro Interdisciplinar de Investigação Marinha e Ambiental, Avenida General Norton de Matos, \\ S/N, 4450-208 Matosinhos, Portugal; catarina.goncalves@ciimar.up.pt (C.G.); vmvascon@fc.up.pt (V.V.) \\ 3 Departamento de Biologia, Faculdade de Ciências, Universidade do Porto, Rua do Campo Alegre S/N, \\ 4169-007 Porto, Portugal \\ * Correspondence: jalmeida@ciimar.up.pt (J.R.A.); m_correiadasilva@ff.up.pt (M.C.-d.-S.) \\ + These authors contributed equally to this work.
}

check for

updates

Citation: Pereira, D.; Gonçalves, C.; Martins, B.T.; Palmeira, A.; Vasconcelos, V.; Pinto, M.; Almeida, J.R.; Correia-da-Silva, M.; Cidade, H. Flavonoid Glycosides with a Triazole Moiety for Marine Antifouling Applications: Synthesis and Biological Activity Evaluation. Mar. Drugs 2021, 19, 5. https:// dx.doi.org/10.3390/md19010005

Received: 5 December 2020

Accepted: 21 December 2020

Published: 24 December 2020

Publisher's Note: MDPI stays neutral with regard to jurisdictional claims in published maps and institutional affiliations.

Copyright: (C) 2020 by the authors. Licensee MDPI, Basel, Switzerland. This article is an open access article distributed under the terms and conditions of the Creative Commons Attribution (CC BY) license (https: / / creativecommons.org/ licenses/by/4.0/).

\begin{abstract}
Over the last decades, antifouling coatings containing biocidal compounds as active ingredients were used to prevent biofouling, and eco-friendly alternatives are needed. Previous research from our group showed that polymethoxylated chalcones and glycosylated flavones obtained by synthesis displayed antifouling activity with low toxicity. In this work, ten new polymethoxylated flavones and chalcones were synthesized for the first time, including eight with a triazole moiety. Eight known flavones and chalcones were also synthesized and tested in order to construct a quantitative structure-activity relationship (QSAR) model for these compounds. Three different antifouling profiles were found: three compounds $(\mathbf{1 b}, \mathbf{1 1 a}$ and $\mathbf{1 1 b})$ exhibited anti-settlement activity against a macrofouling species (Mytilus galloprovincialis), two compounds ( $\mathbf{6} \mathbf{a}$ and $\mathbf{6 b}$ ) exhibited inhibitory activity against the biofilm-forming marine bacteria Roseobacter litoralis and one compound (7b) exhibited activity against both mussel larvae and microalgae Navicula sp. Hydrogen bonding acceptor ability of the molecule was the most significant descriptor contributing positively to the mussel larvae anti-settlement activity and, in fact, the triazolyl glycosylated chalcone $7 \mathrm{~b}$ was the most potent compound against this species. The most promising compounds were not toxic to Artemia salina, highlighting the importance of pursuing the development of new synthetic antifouling agents as an ecofriendly and sustainable alternative for the marine industry.
\end{abstract}

Keywords: flavonoids; synthesis; click chemistry; biofouling; antifouling; eco-friendly alternatives

\section{Introduction}

Marine biofouling, resulting from the accumulation of marine micro and macroorganisms on submerged surfaces, has been a huge problem for maritime industries, causing several technical and economic problems, including corrosion of materials and the increase in fuel consumption. Moreover, marine biofouling is associated with environmental and health problems, due to an increase in gas emissions and the spread of invasive species [1,2].

Biocidal paints containing organotin compounds, namely tributyltin (TBT), were widely used for decades in the maritime industry to prevent biofouling. However, due to their negative effect on the environment and on live organisms, these substances were completely banned in 2008 by the international maritime organization [3]. Since then, some booster biocides, such as Irgarol 1051 or Sea-nine 211, in combination with copper, have been used; nevertheless, even these compounds have demonstrated toxicity on living organisms. 
Therefore, it is imperative to find new antifouling (AF) compounds with environmentally safe characteristics [4-6]. Several non-toxic marine natural products with AF activity have been reported; among them, some flavonoids presented potential AF activity and low toxicity, suggesting their potential as new lead compounds for the development of new AF agents [7].

Previous works from our group reported some glycosylated flavones [8] and chalcones [9] with potential AF activity. Interestingly, when comparing the anti-settlement activity against Mytilus galloprovincialis of previously described chalcones, it seemed that the presence of a polymethoxylated B-ring could be important for this activity [9]. Moreover, the introduction of a triazole moiety is associated with an increase in AF activity [10]. In fact, over the last decade, there has been a great interest in the synthesis of 1,2,3-triazoles due to the fact of these moieties behaved as more than passive linkers. They carried favorable physicochemical properties, showing importance to biological activity $[11,12]$. This approach has been used to generate a vast array of compounds with biological potential [13-16], namely with AF activity [10,17,18]. Moreover, some antimicrobial agents are based on nitrogen heterocycles, including the triazole-based biocides fluconazole and itraconazole, which suggest their potential to act as AF agents [10].

Based on this, the present work aims to synthesize new potential AF polymethoxylated chalcone and flavone derivatives with glycosyl groups incorporating a 1,2,3-triazole moiety using a click chemistry approach. The potential of synthesized compounds as benign AF agents was assessed against the adhesive larvae of the macrofouling mussel Mytilus galloprovincialis and the biofilm-forming marine bacteria Cobetia marina, Vibrio harveyi, Pseudoalteromonas atlantica, Halomonas aquamarina and Roseobacter litoralis. The most promising compounds were submitted to complementary assays to evaluate their viability as AF agents, including the evaluation of possible mechanisms of action related with adhesion and neurotransmission pathways. These compounds were also tested for anti-microalgal activity towards Navicula sp. and general ecotoxicity using nauplii of the marine shrimp Artemia salina.

\section{Results and Discussion}

\subsection{Synthesis and Structure Elucidation}

A series of four glycosylated flavones and four glycosylated chalcones bearing a 1,2,3triazole moiety was synthesized. To prepare glycosylated flavones (Scheme 1), flavones 1a and $\mathbf{1 b}$, used as building blocks, were synthesized by the Mentzer synthesis, through direct thermal cyclocondensation of phloroglucinol and $\beta$-ketoesters, with good yields, as described by Seijas et al. [19]. However, instead of a microwave (MW) irradiation, the synthesis of flavones $1 \mathbf{a}$ and $\mathbf{1 b}$ was performed in a muffle furnace. After, the propargylation of flavones $1 \mathbf{a}$ and $\mathbf{1 b}$ was achieved with propargyl bromide, giving rise to flavones $\mathbf{2 a}$ and $2 \mathrm{~b}$ with $66 \%$ and $55 \%$ yield, respectively. Copper(I)-catalysed azide alkyne cycloaddition (CuAAC), commonly referred as click chemistry, was developed by the Sharpless and Meldal groups in 2002, and is the most useful reaction for the regioselective synthesis of 1,4-disubstituted-1,2,3-triazole ring [20,21]. This involves a reaction of a terminal alkyne and an aliphatic azide using copper (I) as a catalyst in low-time and mild conditions, with high yields and few by-products [20-22]. Therefore, the incorporation of the triazole linked glycosidic moiety in flavones $\mathbf{2} \mathbf{a}$ and $\mathbf{2} \mathbf{b}$ was accomplished by CuAAC under MW irradiation, giving rise to flavones $\mathbf{3 a}, \mathbf{3} \mathbf{b}, \mathbf{4} \mathbf{a}$ and $\mathbf{4} \mathbf{b}$ with $49-82 \%$ yield (Scheme 1 ). 


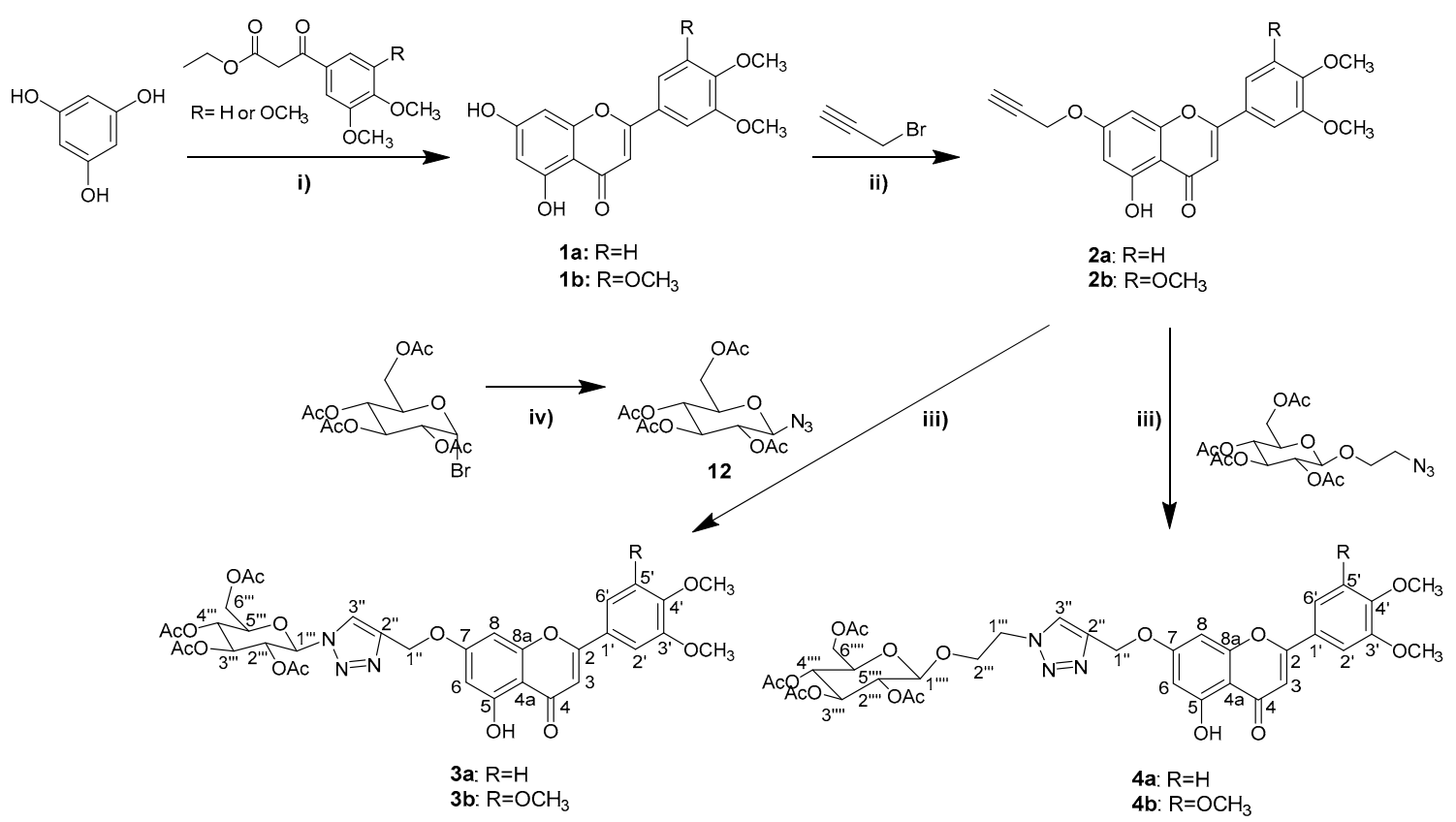

Scheme 1. Synthesis of flavones $\mathbf{1 a}-\mathbf{1 b}, \mathbf{2 a}-\mathbf{2} \mathbf{b}, \mathbf{3 a}-\mathbf{3 b}$ and $\mathbf{4 a}-\mathbf{4 b}$. (i) $240{ }^{\circ} \mathrm{C}, 60-80 \mathrm{~min}, 74-77 \%$; (ii) $\mathrm{Cs}_{2} \mathrm{CO}_{3}$, tetrabutylammonium bromide (TBAB), acetone, $60{ }^{\circ} \mathrm{C}, 6 \mathrm{~h}, 55-66 \%$; (iii) Sodium ascorbate, $\mathrm{CuSO}_{4} .5 \mathrm{H}_{2} \mathrm{O}$, tetrahydrofuran (THF):water, microwave (MW), $30 \mathrm{~min}, 49-82 \%$; (iv) $\mathrm{NaN}_{3}$, acetone:water, r.t., 3 h, $72 \%$.

The first step in the synthetic process to obtain glycosylated chalcones (Scheme 2) was the propargylation of 2,4-dihydroxyacetophenone with propargyl bromide. As for the synthesis of flavones $\mathbf{2} \mathbf{a}-\mathbf{2} \mathbf{b}$, firstly this reaction was accomplished with propargyl bromide, in the presence of anhydrous $\mathrm{Cs}_{2} \mathrm{CO}_{3}$ and tetrabutylammonium bromide (TBAB). Nevertheless, in addition to the desired 4-O-monosubstituted acetophenone (5), the 2,4-disubstituted acetophenone was obtained. Therefore, this reaction was performed in the presence of anhydrous $\mathrm{K}_{2} \mathrm{CO}_{3}$, as described by Zhao et al. [23], with slight modifications, and the 4-O-monosubstituted acetophenone (5) was successfully obtained as expected, with a $76 \%$ yield. Afterwards, the base-catalysed aldol reaction of this propargylated acetophenone with benzaldehydes afforded chalcones $\mathbf{6 a}$ and $\mathbf{6 b}$ with moderate yields, which were subsequently submitted to MW assisted $\mathrm{CuAAC}$ with azide sugar derivatives, affording triazole linked glycosylated chalcones $\mathbf{7 a}, \mathbf{7 b}, \mathbf{8} \mathbf{a}$ and $\mathbf{8 b}$ with $45-65 \%$ yield.

In order to perform structure-activity relationship studies, structure related nonglycosylated chalcones were also synthesized (Scheme 3). Firstly 2,4-dihydroxyacetophenone was protected with methoxymethyl chloride affording 9 with $84 \%$ yield. Chalcones 10a and 10b were prepared by base-catalyzed aldol reaction of 9 and 3,4-dimethoxy- and 3,4,5trimethoxybenzaldehyde with $33 \%$ and $47 \%$ yield, respectively, as described before [24,25], with slight modifications. Chalcones 11a and $\mathbf{1 1} \mathbf{b}$ were obtained with moderate yields by deprotection of methoxymethyl group at C-4' $4^{\prime}$ of intermediate chalcones $10 \mathbf{a}$ and $\mathbf{1 0 b}$, as described by Loureiro et al. [26].

The 2,3,4,6-tetra-O-acetyl- $\beta$-D-glucopyranosyl azide (12), used as a building block for the synthesis of glycosylated derivatives $\mathbf{3 a}, \mathbf{3 b}, \mathbf{7} \mathbf{a}$ and $\mathbf{7 b}$, was synthesized from 2,3,4,6-tetra-O-acetyl- $\alpha$-D-glucopyranosyl bromide and sodium azide, as described by Adesoye et al. [27], with $72 \%$ yield. 


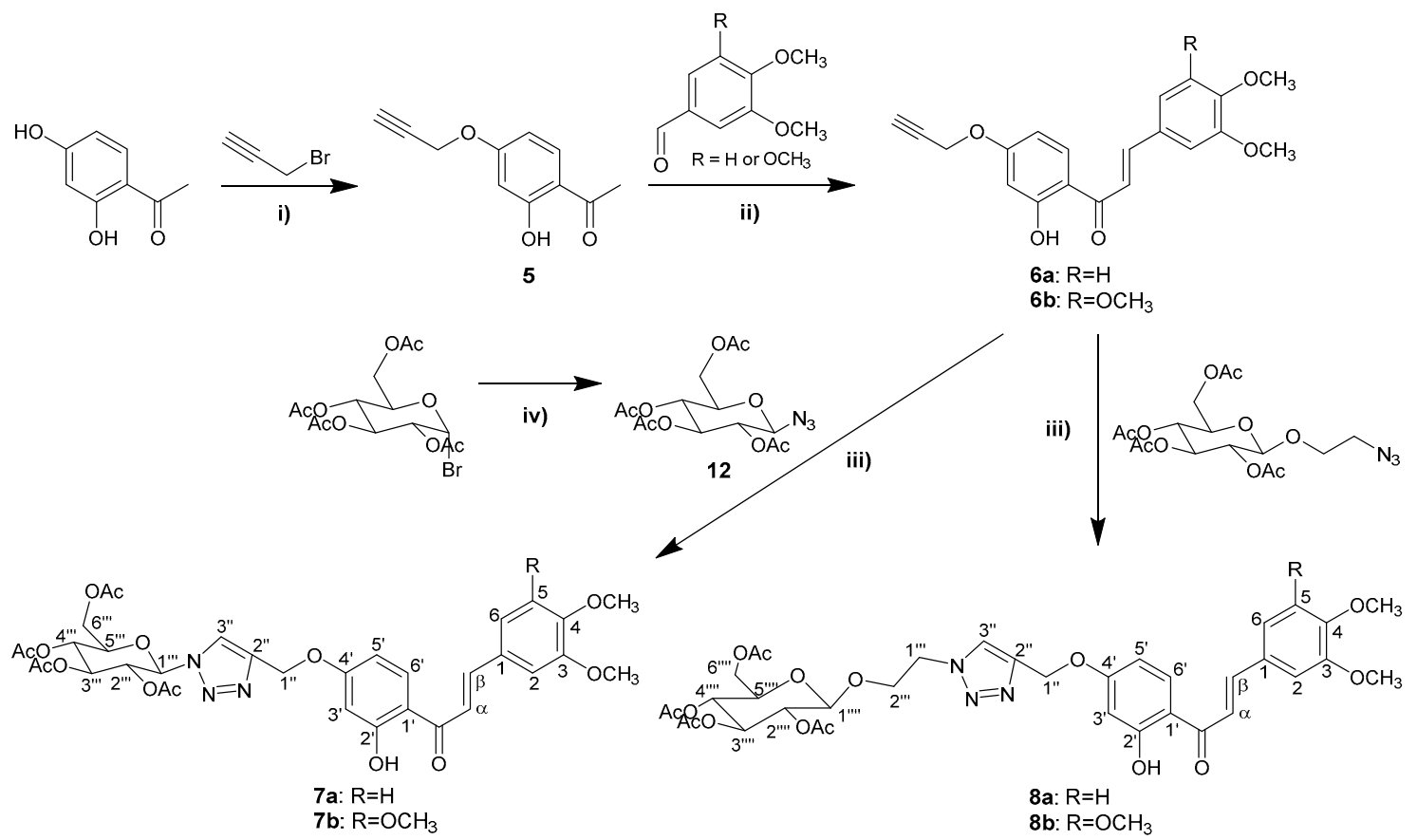

Scheme 2. Synthesis of chalcones $\mathbf{6 a}-\mathbf{6 b}, \mathbf{7 a}-\mathbf{7 b}$ and $\mathbf{8 a}-\mathbf{8 b}$. (i) $\mathrm{K}_{2} \mathrm{CO}_{3}$, acetone, $60{ }^{\circ} \mathrm{C}, 1 \mathrm{~h}, 76 \%$; (ii) $40 \% \mathrm{NaOH}$, methanol, microwave (MW), $3 \mathrm{~h}, 41-43 \%$; (iii) Sodium ascorbate, $\mathrm{CuSO}_{4} .5 \mathrm{H}_{2} \mathrm{O}$, tetrahydrofuran (THF):water, microwave (MW), $1 \mathrm{~h}$, $45-65 \%$; (iv) $\mathrm{NaN}_{3}$, acetone:water, r.t., $3 \mathrm{~h}, 72 \%$.

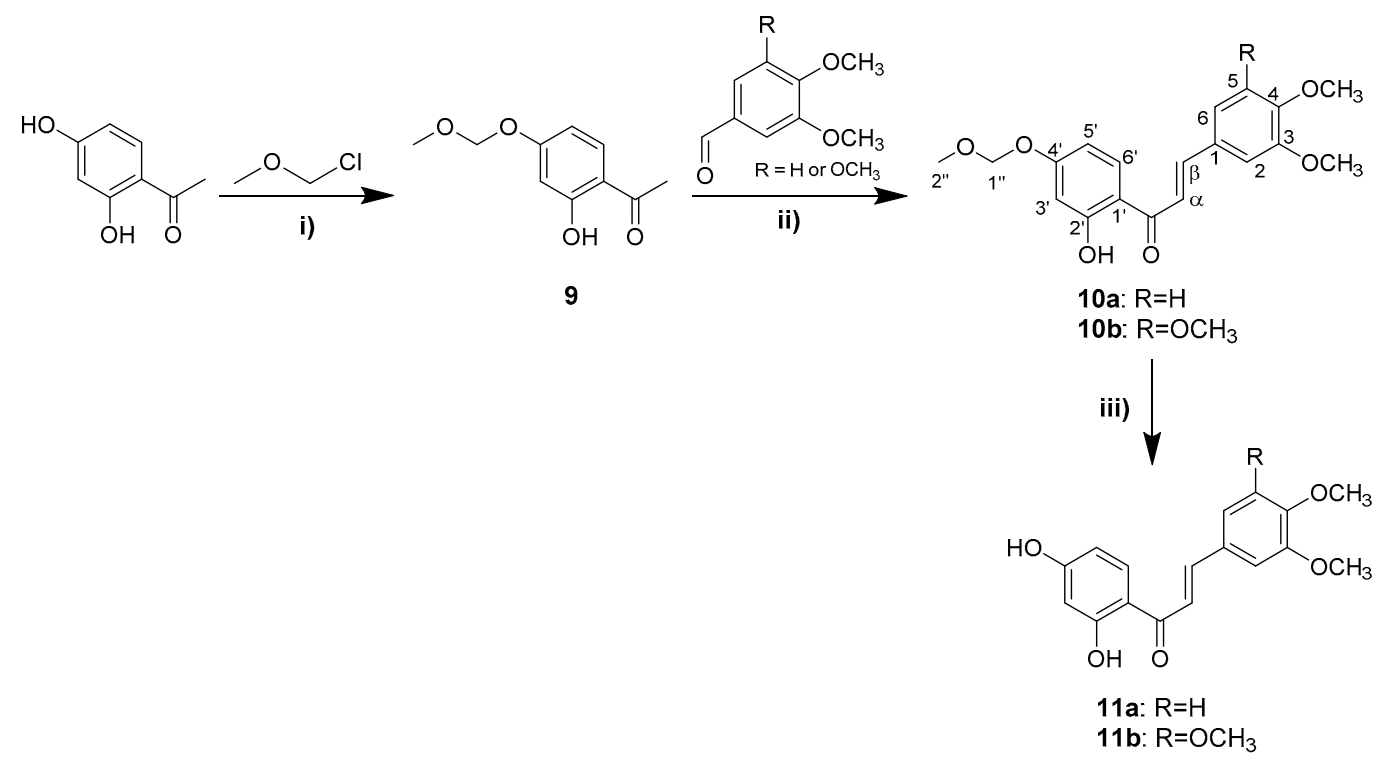

Scheme 3. Synthesis of chalcones 10a-10b and 11a-11b. (i) $\mathrm{K}_{2} \mathrm{CO}_{3}$, acetone, $60{ }^{\circ} \mathrm{C}, 1 \mathrm{~h}, 84 \%$; (ii) $40 \% \mathrm{NaOH}$, methanol, microwave (MW), $4 \mathrm{~h}, 33-47 \%$; (iii) p-Toluenesulfonic acid (PTSA), methanol, $50{ }^{\circ} \mathrm{C}, 5 \mathrm{~h}, 24-31 \%$.

The newly synthesized compounds, $\mathbf{2 a}, \mathbf{2 b}, \mathbf{3 a}, \mathbf{3 b}, \mathbf{4 a}, \mathbf{4 b}, \mathbf{7 a}, \mathbf{7 b}, \mathbf{8 a}$ and $8 \mathbf{b}$ were characterized by high resolution mass spectrometry (HRMS) and nuclear magnetic resonance (NMR). The coupling constants of the vinylic system $\left(\mathrm{J}_{\mathrm{H} \alpha-\mathrm{H} \beta}=15.5-15.3 \mathrm{~Hz}\right)$ confirm the (E)-configuration for all synthesized chalcones. The NMR spectra of the newly synthesized compounds $\mathbf{3 a}, \mathbf{3 b}, \mathbf{4 a}, \mathbf{4 b}, \mathbf{7 a}, \mathbf{7 b}, \mathbf{8} \mathbf{a}$ and $\mathbf{8 b}$ showed characteristic signals for the flavone scaffold and chalcone precursors. Additionally, signals of a triazole ring $\left(\delta \mathrm{H}-3^{\prime \prime}\right.$ $8.61-7.73 \mathrm{~s}, \delta C 2^{\prime \prime} 144.1-141.6$ and $\left.\delta C 3^{\prime \prime} 125.2-121.5\right)$ and a glycosyl moiety were observed. The position of the triazole ring on these compounds was evidenced by the correlation 
found in the heteronuclear multiple bond correlation ( $\mathrm{HMBC}$ ) spectra between the proton signals of $\mathrm{H}-1^{\prime \prime}$ and the carbon signals of $\mathrm{C}-2^{\prime \prime}$ and $\mathrm{C}-3^{\prime \prime}$.

\subsection{Mussel (Mytilus galloprovincialis) Larvae Anti-Settlement Activity}

Mussels are one of the main macrofouling organisms present on ships and submerged maritime structures worldwide; thus, they are a target species used in settlement inhibition bioassays [28,29]. Due to the presence of a muscular sensory foot, mussel plantigrade larvae are highly specialized in adhesion to the submerged surfaces and the fixation is made through the production of byssal threads [30], which constitutes the endpoint of this bioassay. Therefore, for the evaluation of the AF activity of the compounds towards macrofouling species, the ability of the synthetized flavonoids to inhibit the settlement of Mytilus galloprovincialis larvae at $50 \mu \mathrm{M}$ was assessed. In this screening bioassay, in addition to glycosylated flavones $3 \mathbf{a}, 3 \mathbf{b}, \mathbf{4} \mathbf{a}$ and $\mathbf{4 b}$ and chalcones $7 \mathbf{a}, 7 \mathbf{b}, \mathbf{8} \mathbf{a}$ and $8 \mathbf{b}$, non-glycosylated flavones $\mathbf{1 a}-\mathbf{b}$ and $\mathbf{2} \mathbf{a}-\mathbf{b}$ and chalcones $\mathbf{6 a}-\mathbf{b}, \mathbf{1 0} \mathbf{a}-\mathbf{b}$ and $11 \mathbf{a}-\mathbf{b}$ were tested in order to perform SAR studies. Results showed that among 18 tested flavonoids (10 chalcones and 8 flavones), seven chalcones $(\mathbf{6 a}, \mathbf{6} \mathbf{b}, \mathbf{7 b}, \mathbf{8 a}, \mathbf{8 b}, \mathbf{1 1} \mathbf{a}$ and $\mathbf{1 1} \mathbf{b})$ and only three flavones (1b, $\mathbf{4 a}$ and $\mathbf{4 b}$ ) presented a percentage of settlement $\leq 40 \%$, suggesting that chalcone scaffold seems to be more promising for anti-settlement activity. These 10 compounds were further selected for dose-response studies in order to determine $\mathrm{LC}_{50} / \mathrm{EC}_{50}$ values.

Among these, three chalcones $(\mathbf{7 b}, \mathbf{1 1 a}, \mathbf{1 1 b})$ and one flavone $(\mathbf{1 b})$ revealed effective anti-settlement activity $\left(\mathrm{EC}_{50}<25 \mu \mathrm{g} / \mathrm{mL}\right.$ ), with triazolyl glycosylated chalcone $7 \mathbf{b}$ being the most potent $\left(\mathrm{EC}_{50}=3.28 \mu \mathrm{M} ; 2.43 \mu \mathrm{g} \cdot \mathrm{mL}^{-1}\right)$, showing the highest therapeutic ratio (> 60.98) (Table 1).

Table 1. Antifouling (AF) effectiveness and toxicity parameters of flavones $\mathbf{1 b}, \mathbf{4 a}$ and $\mathbf{4 b}$ and chalcones $6 \mathrm{a}, \mathbf{6 b}, \mathbf{7 b}, \mathbf{8 a}, \mathbf{8 b}, \mathbf{1 1} \mathrm{a}$ and $\mathbf{1 1 b}$ towards mussel plantigrade larvae.

\begin{tabular}{|c|c|c|c|c|}
\hline Compound & $\mathrm{EC}_{50}(\mu \mathrm{M})$ & $\mathrm{EC}_{50}\left(\mu \mathrm{g} \cdot \mathrm{mL}^{-1}\right)$ & $\mathrm{LC}_{50}(\mu \mathrm{M})$ & $\mathrm{LC}_{50} / \mathrm{EC}_{50}$ \\
\hline $1 b$ & $\begin{array}{c}8.34 \text { (95\% CI: } \\
4.2-13.36)\end{array}$ & 2.87 & $>200$ & $>23.98$ \\
\hline $4 a$ & $\begin{array}{c}42.55 \text { (95\% CI: } \\
34.90-52.80)\end{array}$ & 32.75 & $>200$ & $>4.70$ \\
\hline $4 b$ & $\begin{array}{c}48.22 \text { (95\% CI: } \\
\text { 30.57-85.40) }\end{array}$ & 38.56 & $>200$ & $>4.15$ \\
\hline $6 a$ & $\begin{array}{l}84.52 \text { (95\% CI: } \\
45.07-267.02)\end{array}$ & 28.60 & $>200$ & $>2.37$ \\
\hline $6 b$ & $\begin{array}{l}85.56 \text { (95\% CI: } \\
44.84-291.41)\end{array}$ & 31.52 & $>200$ & $>2.34$ \\
\hline $7 b$ & $\begin{array}{c}3.28 \text { (95\% CI: } \\
1.97-4.74)\end{array}$ & 2.43 & $>200$ & $>60.98$ \\
\hline $8 a$ & $\begin{array}{c}35.83 \text { (95\% CI: } \\
19.22-74.74)\end{array}$ & 27.07 & $>200$ & $>5.58$ \\
\hline $8 b$ & $\begin{array}{l}53.90 \text { (95\% CI: } \\
29.98-126.88)\end{array}$ & 42.35 & $>200$ & $>3.71$ \\
\hline $11 a$ & $\begin{array}{c}18.10 \text { (95\% CI: } \\
13.95-23.44)\end{array}$ & 5.44 & $>200$ & $>11.05$ \\
\hline $11 b$ & $\begin{array}{c}9.64 \text { (95\% CI: } \\
3.85-17.22)\end{array}$ & 3.18 & $>200$ & $>20.75$ \\
\hline
\end{tabular}

$\mathrm{EC}_{50}$ : minimum concentration that inhibited $50 \%$ of larval settlement; $\mathrm{LC}_{50}$ : median lethal dose; $\mathrm{LC}_{50} / \mathrm{EC}_{50}$ : therapeutic ratio; $\mathrm{CI}$ : confidence interval. $\mathrm{EC}_{50}$ are recommend to be less than $25 \mu \mathrm{g} / \mathrm{mL}$ and therapeutic ratio higher than 15 for effective AF agents [31].

\subsection{Quantitative Structure-Activity Relationship}

Quantitative structure-activity relationship (QSAR) studies have been used for several years to point out small molecules' properties that are relevant for activity, and to forecast the activity of new compounds [32]. Therefore, a QSAR model was built to highlight the 
descriptors that are being relevant for anti-settlement activity against M. galloprovincialis plantigrades of the tested flavonoids. In this work, a 2D-QSAR model was elaborated using the Comprehensive Descriptors for Structural and Statistical Analysis (CODESSA 2.7.2) software package, which calculates approximately 500 descriptors. The heuristic method performs a pre-selection of descriptors by eliminating descriptors that are not available for each structure, that have a small variation in magnitude, that are correlated pairwise, and that have no statistical significance. The heuristic method is a very useful method for searching the best set of descriptors, without restrictions on the data set size [33].

The correlation coefficient $\left(R^{2}\right)$, squared standard error $\left(S^{2}\right)$, and Fisher's value $(F)$ were used to evaluate the validity of regression equation [34]. As the rules of QSAR establish that there must be one descriptor for each five molecules used to build the model [34], three descriptors were used to build the QSAR equation. The multilinear regression analysis using Heuristic method for 15 compounds in the three-descriptor model is shown in Figure 1. The compounds are uniformly distributed around the regression line (Figure 1), which suggests that the obtained model has satisfactory predictive ability.

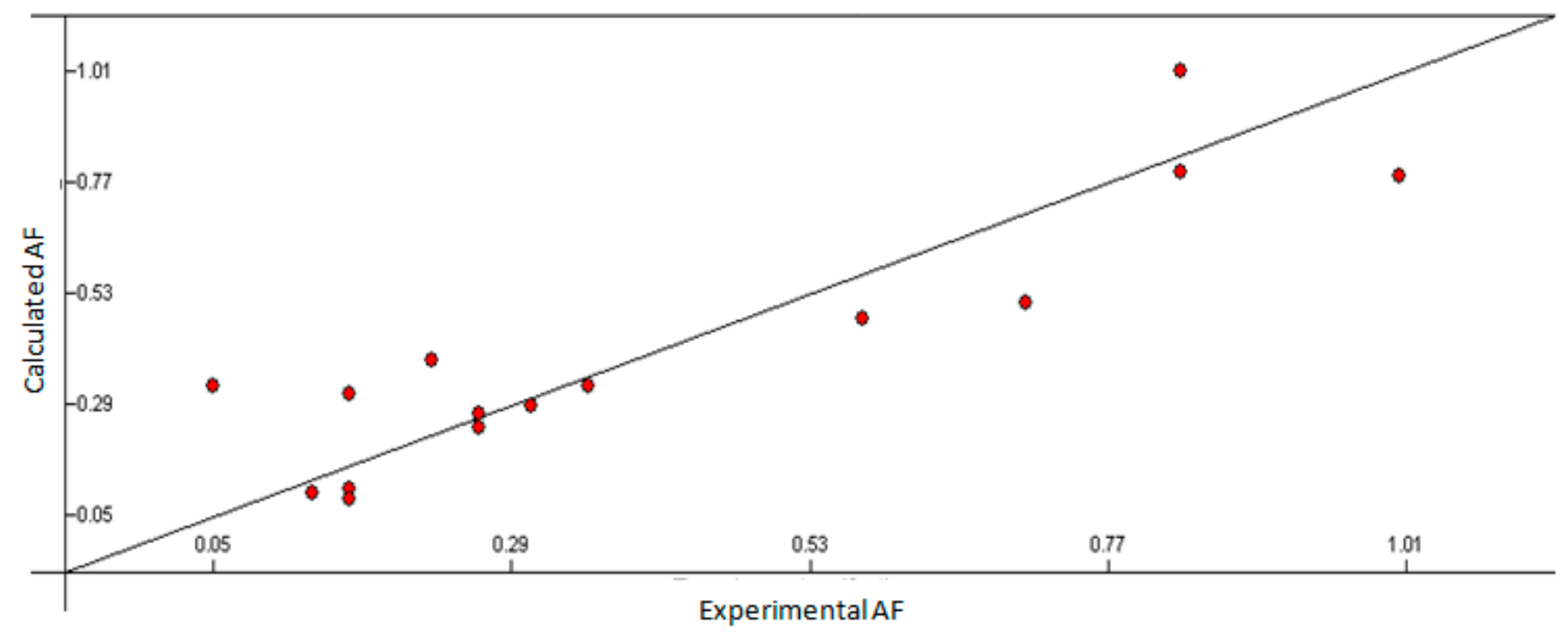

\begin{tabular}{ccccl}
\hline $\mathbf{N r}$ & $\mathbf{X}$ & $\Delta \mathbf{X}$ & $\mathbf{t}-$ test & Descriptor \\
0 & 0.3730 & 0.3417 & 1.0915 & Intercept \\
1 & 0.1267 & 0.02264 & 5.5960 & Hydrogen bonding acceptor ability of the molecule - HACA1 \\
2 & -0.9101 & 0.2645 & -3.4416 & Average Complementary Information content (order 2) \\
3 & -0.2867 & 0.1532 & -1.8721 & Number of triple bonds \\
\hline
\end{tabular}

Figure 1. Quantitative structure-activity relationship (QSAR) model obtained with the heuristic method for 15 molecules with the CODESSA software $\left(R^{2}=0.7945, F=14.18, S^{2}=0.0243\right) . X, \Delta X$ and $t$-test are the regression coefficient of the linear model, standard errors of the regression coefficient, and the $t$ significance coefficient of the determination, respectively. $\mathrm{AF}=$ antifouling activity.

The best QSAR equation had a $\mathrm{R}^{2}$ of 0.7945 , Fisher value of 14.18 , and $\mathrm{S}^{2}$ of 0.0243 , which reveals that the proposed model has statistical validity [35]. The $\mathrm{R}^{2}$ is higher than 0.6 , which is an indicator of a good fit to the regression line [36], representing close to $80 \%$ of the total variance in AF activity shown by the test compounds. The QSAR model is significant at a $95 \%$ level, as shown by the Fisher F-test $(\mathrm{F}=14.18)$, which is higher than the tabulated value (3.59), as desired for a statistically significant model [35]. The squared standard deviation $S^{2}$ is small and close to zero $\left(s^{2}=0.0243\right)$, proving that the model is significant and has low variation about the regression line [37]. The reliability of the resulting QSAR model was explored using two different types of validation criteria: external validation by using a test set and internal validation by leave-one-out (LOO) cross-validation [38]. 
The model was able to predict the activity of an external test set with an average difference of 0.19 from the experimental value [39]. Moreover, the cross-validated $R^{2}\left(Q^{2}=0.5953\right)$ from the LOO internal validation process is higher than 0.5 and smaller than the overall $\mathrm{R}^{2}$, as expected, and the difference between $R^{2}$ and $Q^{2}$ is lower than 0.3 , which indicates that the model does not suffer from overfitting [40].

By interpreting the molecular descriptors in the regression model (Figure 1), it is possible to have some insight into structural characteristics that are likely to be responsible for AF activity of the studied compounds. There are three descriptors included in the regression model, which proved to be important features and provide statistically significant contributions to the QSAR equation.

As indicated by the higher t-test value, hydrogen bonding acceptor ability of the molecule (HACA1) is a charged partial surface area (CPSA) descriptor that appeared as the most significant descriptor for the obtained QSAR model, contributing positively to the AF activity [41]. HACA1 is determined by the equation:

$$
\mathrm{HACA} 1=\sum_{\mathrm{A}} \mathrm{S}_{\mathrm{A}} \mathrm{A} \in \mathrm{X}_{\mathrm{H}-\text { acceptor }}
$$

where $S_{A}$ stands for solvent-accessible surface area of $\mathrm{H}$-bonding acceptor atoms, selected by threshold charge. This descriptor proves the importance of the hydrogen bonding acceptor properties for the activity of the test compounds [42].

The topological descriptor average complementary information content of order 2 (CIC2) descriptor is predicted as being negatively implied in the AF activity of the test compounds [41]. The CIC2 descriptor represents the difference between the maximum possible complexity of a molecule and its real topological information. It belongs to the multi-graph information content indices and it describes neighborhood symmetry of second order [43]. The constitutional descriptor number of triple bonds is also responsible for a decrease in activity.

The molecular descriptors used in the QSAR model demonstrate that the mechanism underlying the AF activity of flavonoids is mainly related to their HACA1, and it may be prejudiced by topological CIC2 and by the presence of triple bonds. Interestingly, the triazolyl glycosylated chalcone $\mathbf{7 b}$, with the most promising anti-settlement activity, is one of the compounds with more hydrogen-bonding acceptors. In contrast, propargylated flavones $\mathbf{2} \mathbf{a}$ and $\mathbf{2} \mathbf{b}$ had a percentage of settlement higher than $40 \%$ at $50 \mu \mathrm{M}$, and therefore were not selected for dose-response studies and for the determination of the $\mathrm{LC}_{50} / \mathrm{EC}_{50}$ values. Moreover, propargylated chalcones $\mathbf{6 a}$ and $\mathbf{6} \mathbf{b}$ showed the lowest activity. Overall, the examination of the molecular descriptors reported in this work can lead to a better understanding of the relation between the structure and AF activity of flavonoids.

\subsection{Biofilm-Forming Marine Bacteria Growth Inhibitory Activity}

Although the macrofouling species represent the most problematic component of fouling in terms of biomass and negative repercussions, the first micro-colonizers are also of extreme importance, since they represent the basis of the fouling community, and ultimately, they may modulate the colonization of further species by inducing or inhibiting species adhesion via biochemical cues [44]. Thus, synthesized flavonoids were further evaluated for their ability to inhibit the growth of five marine biofilm-forming bacteria, Vibrio harveyi, Cobetia marina, Halomonas aquamarina, Pseudoalteromonas atlantica and Roseobacter litoralis.

Results showed that only the bacterial growth of Roseobacter litoralis was meaningfully compromised by tested compounds, with significant inhibitory activity for propargylated chalcones $\mathbf{6 a}$ and $\mathbf{6 b}$ (Figure 2). These compounds were selected for concentration-response analysis (Figure 3). 


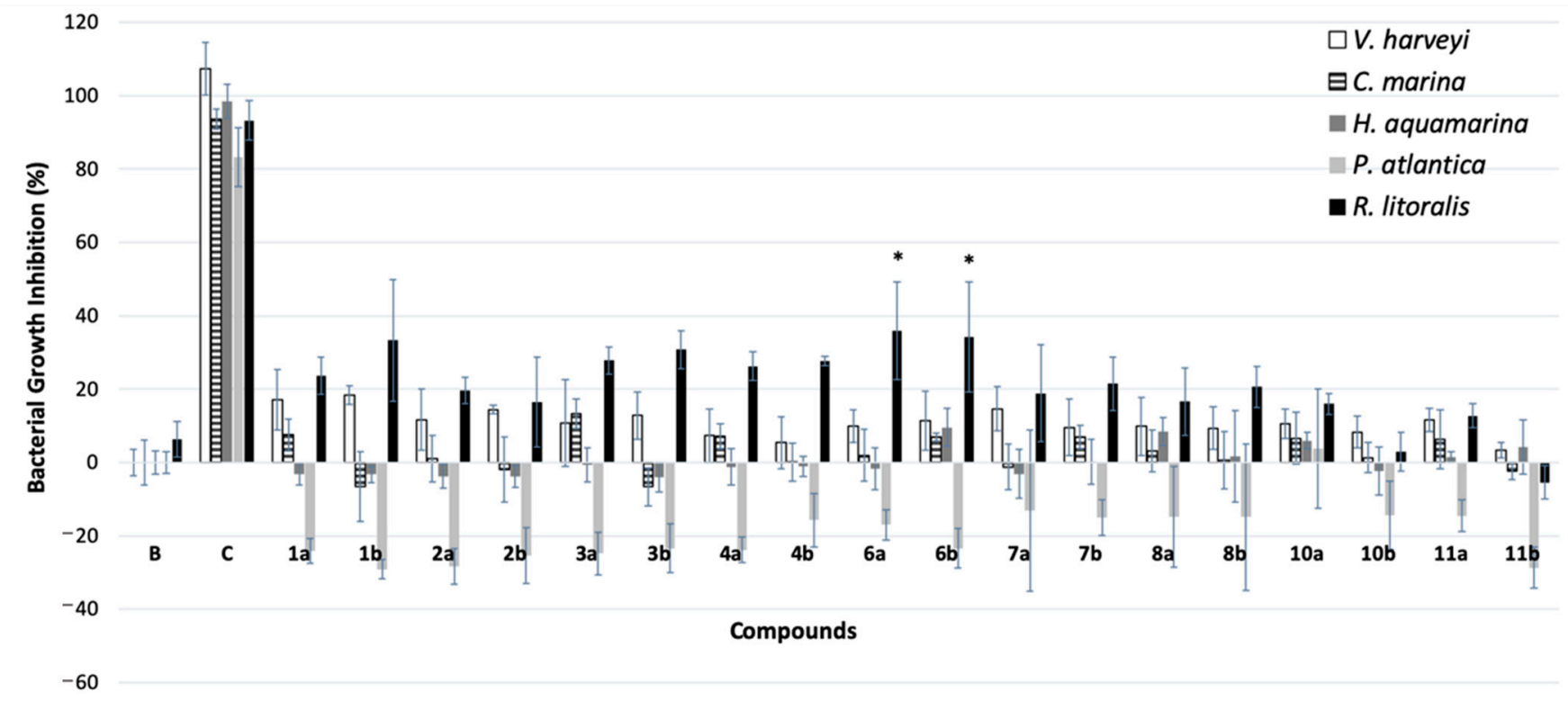

Figure 2. Bacterial growth inhibition screening of flavonoid derivatives (15 $\mu \mathrm{M})$ towards five biofilm-forming marine bacteria: Vibrio harveyi, Cobetia marina, Halomonas aquamarina, Pseudoalteromonas atlantica and Roseobacter litoralis. B: Negative control with 1\% dimethyl sulfoxide (DMSO); C: positive control with penicillin-streptomycin-neomycinstabilized solution. * indicates significant differences at $p<0.05$ (Dunnett test), against the negative control (B).

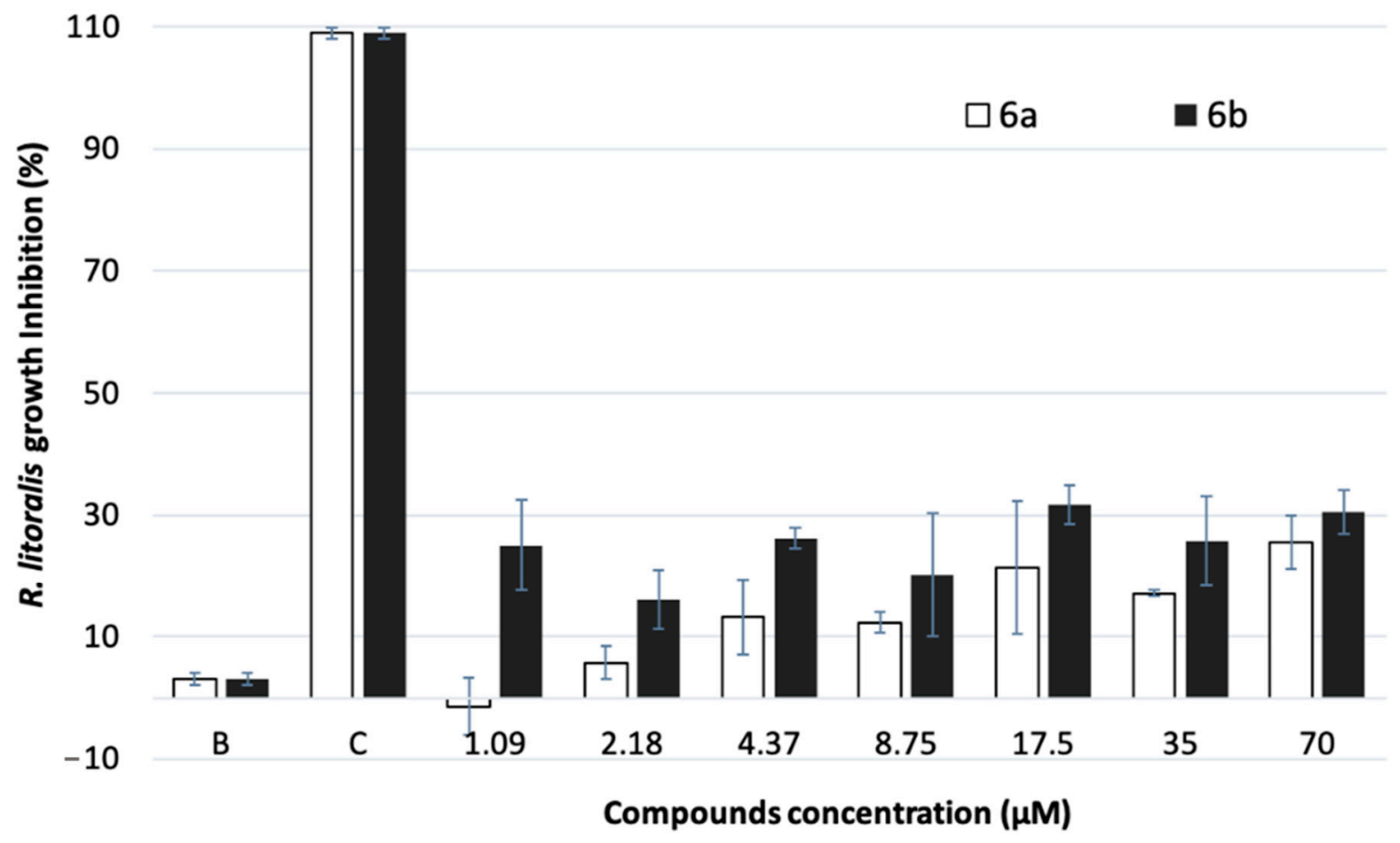

Figure 3. Concentration-response growth inhibition activity of compounds $\mathbf{6 a}$ and $\mathbf{6} \mathbf{b}$ towards Roseobacter litoralis. B: DMSO negative control; C: positive control with penicillin-streptomycin-neomycin-stabilized solution.

Compounds $\mathbf{6 a}$ and $\mathbf{6 b}$ presented low anti-bacterial activity towards $R$. litoralis with $\mathrm{EC}_{30}$ values of 135 and $83.5 \mu \mathrm{M}$, respectively.

\subsection{Biofilm-Forming Marine Diatoms Growth Inhibitory Activity}

The most promising compounds regarding anti-settlement activity $(\mathbf{1 b}, \mathbf{7 b}, \mathbf{1 1 a}, \mathbf{1 1} \mathbf{b})$ were further evaluated for their ability to inhibit the growth of the biofilm-forming 
microalgae Navicula sp. This marine diatom is a major biofouling species that very effectively colonizes submerged surfaces by secreting adhesive extracellular polymer substances (EPS), and thus is a good representative of fouling microalgae.

Only triazolyl glycosylated chalcone $\mathbf{7 b}$ showed significant inhibitory activity with the concentration-response analyses revealing an $\mathrm{EC}_{50}$ value of $41.76 \mu \mathrm{M} ; 30.94 \mu \mathrm{g} \cdot \mathrm{mL}^{-1}$, suggesting the ability of this compound to act also as a promising AF agent against microfouling species.

\subsection{In Vitro Acetylcholinesterase (AChE) and Tyrosinase (Tyr) Activities}

The identification of the mechanism of action associated with AF activity remains a challenge for the scientific community. According to Qian et al. (2013) antifoulants appear to affect settlement through distinct pathways, which can be classified roughly into several categories such as inhibitors of ion channel function, inhibitors of quorum sensing, blockers of neurotransmission or inhibitors of adhesive production or release [45]. Moreover, some specific target molecules in fouling organisms have been determined, such as AChE, which seems to be involved in cholinergic neural signaling during the settlement [46]. It is known that the commercial booster biocide Sea-Nine 211 acts by this mechanism $[47,48]$, as well as two natural compounds isolated from marine organisms, territrem A and pulmonarin [49,50]. For this reason, the ability of the most promising compounds to modulate the activity of $\mathrm{AChE}$ was evaluated $(\mathbf{1 b}, \mathbf{7 b}, \mathbf{1 1} \mathbf{a}$ and $\mathbf{1 1 b})$. $\mathrm{AChE}$ activity was significantly induced for chalcones $\mathbf{7 b}$ and $\mathbf{1 1} \mathbf{b}$ (Figure 4). Induced AChE activity has been described as an exposure effect that is in some cases associated with apoptosis [51], and thus the specific target behind these compounds' bioactivity should be further explored in future work.

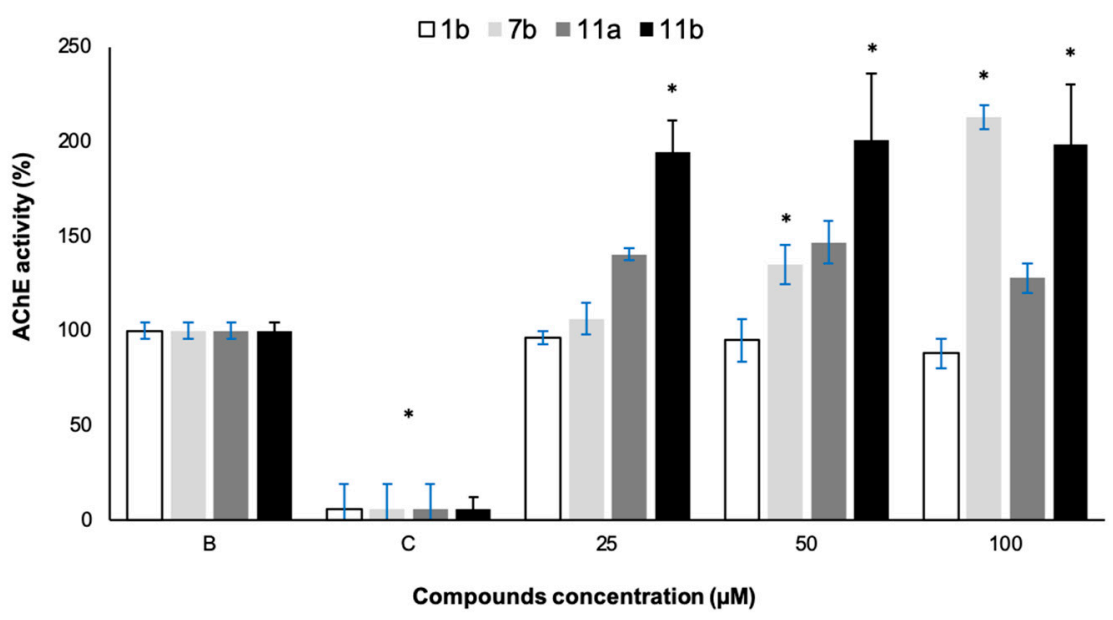

Figure 4. AChE activity of the most promising compounds $\mathbf{1 b} \mathbf{7 b}, \mathbf{1 1} \mathbf{a}$ and $\mathbf{1 1} \mathbf{b}$. B: Dimethyl sulfoxide (DMSO) (1\% in water). C: Eserine $\left(200 \mu \mathrm{M}\right.$, water). ${ }^{*}$ indicates significant differences at $p<0.05$ (Dunnett test), against the negative control (B).

A well-known pathway in the production of biological adhesives of mussels is the 3,4-dihydroxyphenyl-L-alanine (L-DOPA) metabolism that functions in the production of DOPA-containing mussel byssal plaques by the action of Tyr that catalyses the conversion of DOPA precursor into DOPA residues [46,52]. Considering this, the most promising compounds in the inhibition of mussel adhesion were tested for their ability to inhibit Tyr (Figure 5). Results show that flavone $\mathbf{1 b}$ is able to significantly decrease Tyr activity at all the concentrations tested, reaching $23.5 \%$ of inhibition at $100 \mu \mathrm{M}$. Therefore, the inhibition of this enzyme, with a crucial effect in the formation of mussel adhesive, could be one of the mechanisms involved in the inhibition of the mussel settlement. This also highlights a specific AF mode of action related with mussel adhesion and explains the absence of activity against bacteria and diatoms. 


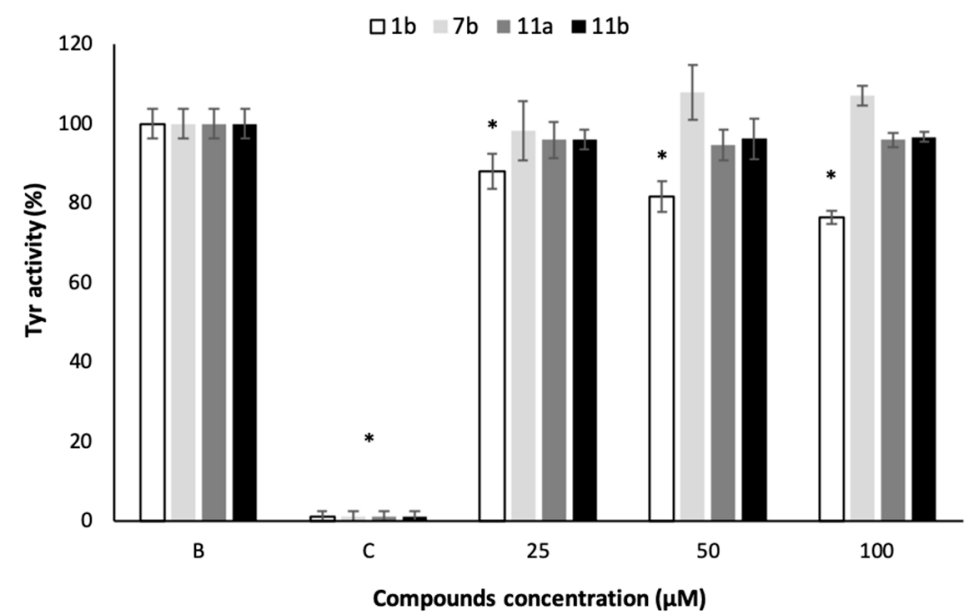

Figure 5. Tyr activity of the most promising compounds $\mathbf{1 b}, \mathbf{7 b}, \mathbf{1 1 a}$ and $\mathbf{1 1 b}$. B: Dimethyl sulfoxide (DMSO) (1\% in water). C: Kojic acid (1.4 mM, water). * indicates significant differences at $p<0.05$ (Dunnett test), against the negative control (B).

\subsection{Environmental Fate Parameters: Artemia Salina Ecotoxicity Bioassay}

Ecotoxicity assays carried out on non-target organisms aim to understand how tested compounds can affect sensitive non-target organisms and influence the health status of the surrounding ecosystem [53]. Artemia salina is a species of small crustaceans that live in salty marine environments and are used as test organisms because of their easy culture, short generation time, cosmopolitan distribution and commercial availability of their eggs in latent form [54].

Ecotoxicity results showed that the most promising compounds $\mathbf{1 b}, \mathbf{7 b}, \mathbf{1 1 a}$ and $\mathbf{1 1 b}$ are non-toxic to Artemia salina (less than $10 \%$ mortality) at both concentrations tested $(25$ and $50 \mu \mathrm{M})$ (Figure 6), in contrast to the commercial AF agent ECONEA ${ }^{\circledR}$ which was previously shown by our group to cause $100 \%$ lethality at the same concentrations and conditions [9]. These results suggest that any of the tested compounds could be a good alternative, being more environmentally compatible antifoulants.

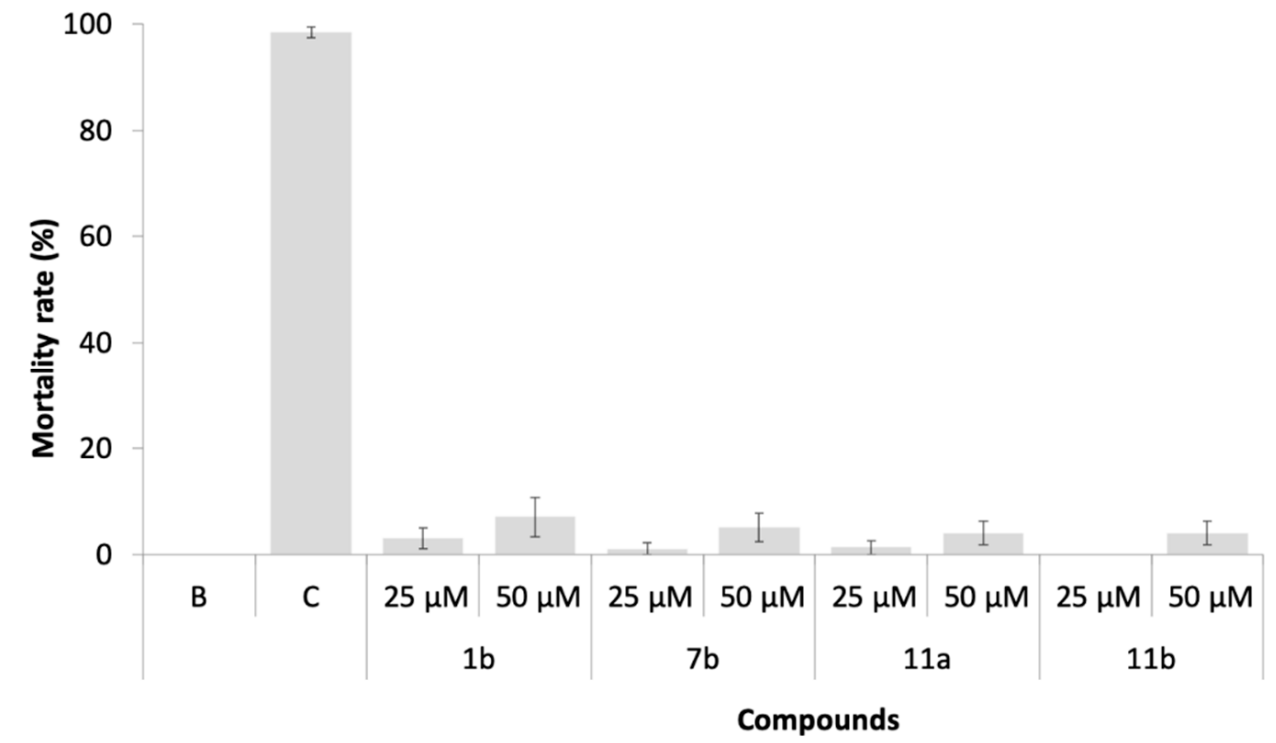

Figure 6. Mortality rate of Artemia salina nauplii after $48 \mathrm{~h}$ of exposure to compounds $\mathbf{1 b}, \mathbf{7 b}, \mathbf{1 1 a}$ and 11b, B: DMSO (1\% in filtered seawater). $\mathrm{C}: \mathrm{K}_{2} \mathrm{Cr}_{2} \mathrm{O}_{7}(13.6 \mu \mathrm{M}$, filtered seawater). 


\section{Materials and Methods}

\subsection{Synthesis and Structure Elucidation of Chalcones and Flavones}

MW reactions were performed using a glassware setup for atmospheric pressure reactions and a $100 \mathrm{~mL}$ Teflon reactor (internal reaction temperature measurements with a fiber-optic probe sensor) and were carried out using an Ethos MicroSYNTH 1600 Microwave Labstation from Milestone (Thermo Unicam, Oeiras, Portugal). The reactions were monitored by analytical thin-layer chromatography (TLC) Macherey-Nagel Silica gel 60 F254 (Macherey-Nagel, Dueren, Germany), Purifications of compounds were carried out by flash chromatography using Macherey-Nagel silica gel $60(0.04-0.063 \mathrm{~mm})$ (MachereyNagel, Dueren, Germany), preparative TLC using Macherey-Nagel silica gel 60 (GF254) (Macherey-Nagel, Dueren, Germany) plates and crystallization. Melting points were obtained in a Köfler microscope (Wagner and Munz, Munich, Germany) and are uncorrected. ${ }^{1} \mathrm{H}$ and ${ }^{13} \mathrm{C}$ NMR spectra were taken in $\mathrm{CDCl}_{3}$ or DMSO- $\mathrm{d}_{6}$ at room temperature, on Bruker Avance 300 and 500 instruments (Bruker Biosciences Corporation, Billerica, MA, USA) (300.13 MHz or $500 \mathrm{MHz}$ for ${ }^{1} \mathrm{H}$ and 75.47 or $120 \mathrm{MHz}$ for $\left.{ }^{13} \mathrm{C}\right)$. Chemical shifts are expressed in $\delta(\mathrm{ppm})$ values relative to tetramethylsilane (TMS) as an internal reference; ${ }^{13} \mathrm{C}$ NMR assignments were made by 2D (HSQC and HMBC) NMR experiments (longrange ${ }^{13} \mathrm{C}-{ }^{1} \mathrm{H}$ coupling constants were optimized to $7 \mathrm{~Hz}$ ). HRMS mass spectra of compounds $\mathbf{2 a}, \mathbf{2} \mathbf{b}, \mathbf{3 a}, \mathbf{3 b}, \mathbf{4 a}, \mathbf{4 b}, \mathbf{7 a}, \mathbf{7 b}$ and $\mathbf{8 b}$ were performed on an APEXQe FT-ICR MS (Bruker Daltonics, Billerica, MA) equipped with a 7T actively shielded magnet, at C.A.C.T.I.-University of Vigo, Spain. Ions were generated using a Combi MALDIelectrospray ionization (ESI) source. HRMS mass spectrometry of compound 8a was performed on an LTQ Orbitrap ${ }^{\mathrm{TM}}$ XL hybrid mass spectrometer (Thermo Fischer Scientific, Bremen, Germany) controlled by LTQ Tune Plus 2.5.5 and Xcalibur 2.1.0. at CEMUPUniversity of Porto, Portugal. Phloroglucinol, ethyl 3,4-dimethoxybenzoylacetate, ethyl 3,4,5-trimethoxybenzoylacetate, 2,4-dihydroxyacetophenone and 2,3,4,6-tetra-O-acetyl$\alpha$-D-glucopyranosyl bromide were purchased from Sigma Aldrich (St. Louis, MO, USA). 3,4-Dimethoxybenzaldehyde and 3,4,5-trimethoxybenzaldehyde were purchased from Acros Organics (Janssen Pharmaceuticalaan, Geel, Belgium). 2-Azidoethyl-2,3,4,6-tetra-Oacetyl- $\beta$-D-glucopyranoside was purchased from Synthose (Concord, ON, Canada).

\subsubsection{Synthesis of Flavones $\mathbf{1 a}$ and $\mathbf{1 b}$}

A mixture of phloroglucinol $(0.175 \mathrm{~g}, 1.39 \mathrm{mmol})$ and ethyl 3,4-dimethoxybenzoylacetate $(0.700 \mathrm{~g}, 2.78 \mathrm{mmol})$ or ethyl 3,4,5-trimethoxybenzoylacetate $(0.739 \mathrm{~g}, 2.78 \mathrm{mmol})$ was heated at $240{ }^{\circ} \mathrm{C}$ in muffle furnace (Thermo Fisher Scientific, Oeiras, Portugal) for 60-100 min. Afterwards, the crude mixture was dissolved in $10 \% \mathrm{NaOH}(20 \mathrm{~mL})$ and washed with diethyl ether $(2 \times 20 \mathrm{~mL})$, and the product was precipitated by adding $37 \% \mathrm{HCl}$. The solid was filtered and washed with water, and the flavones $\mathbf{1 a}$ and $\mathbf{1 b}$ were obtained with $74 \%$ and $77 \%$ yields, respectively. The structure elucidation of compounds $1 \mathrm{a}$ and $\mathbf{2 b}$ was established by ${ }^{1} \mathrm{H}$ and ${ }^{13} \mathrm{C}$ NMR techniques and data were in accordance with previously reported results [19].

\subsubsection{Synthesis of 7-O-Propargylflavones $\mathbf{2 a}$ and $\mathbf{2} \mathbf{b}$}

To a solution of $1 \mathbf{a}(0.200 \mathrm{~g}, 0.64 \mathrm{mmol})$ or $\mathbf{1 b}(0.200 \mathrm{~g}, 0.58 \mathrm{mmol})$, cesium carbonate $(0.207 \mathrm{~g}, 0.64 \mathrm{mmol}$ or $0.189 \mathrm{~g}, 0.58 \mathrm{mmol})$, tetrabutylammonium bromide (TBAB) $(0.205 \mathrm{~g}$, $0.64 \mathrm{mmol}$ or $0.187 \mathrm{~g}, 0.58 \mathrm{mmol})$ in anhydrous acetone $(20 \mathrm{~mL})$, and propargyl bromide solution, $80 \mathrm{wt} . \%$ in toluene $(0.071 \mathrm{~mL}, 0.64 \mathrm{mmol}$ or $0.065 \mathrm{~mL}, 0.58 \mathrm{mmol})$, were added. The mixture was refluxed at $60{ }^{\circ} \mathrm{C}$ during $6 \mathrm{~h}$ and filtered. The filtrate was evaporated under reduced pressure and purification was carried out by flash column chromatography $\left(\mathrm{SiO}_{2}\right.$; n-hexane: ethyl acetate), 8:2) followed by crystallization in acetone.

2-(3,4-dimethoxyphenyl)-5-hydroxy-7-(prop-2-yn-1-yloxy)-4H-chromen-4-one (2a). Light yellow solid; Yield: $66 \%$; m.p.: $222-224{ }^{\circ} \mathrm{C}$ (acetone); ${ }^{1} \mathrm{H}$ NMR (DMSO-d $\left.6,500 \mathrm{MHz}\right), \delta$ : $12.93(1 \mathrm{H}, \mathrm{s}, \mathrm{OH}-5), 7.71\left(1 \mathrm{H}, \mathrm{dd}, \mathrm{J}=8.5\right.$ and $\left.2.2 \mathrm{~Hz}, \mathrm{H}-6^{\prime}\right), 7.57\left(1 \mathrm{H}, \mathrm{d}, \mathrm{J}=2.2 \mathrm{~Hz}, \mathrm{H}-2^{\prime}\right)$, $7.14\left(1 \mathrm{H}, \mathrm{d}, \mathrm{J}=8.7 \mathrm{~Hz}, \mathrm{H}-5^{\prime}\right), 7.03(1 \mathrm{H}, \mathrm{s}, \mathrm{H}-3), 6.87(1 \mathrm{H}, \mathrm{d}, \mathrm{J}=2.2 \mathrm{~Hz}, \mathrm{H}-8), 6.44(1 \mathrm{H}, \mathrm{d}$, 
$\mathrm{J}=2.3 \mathrm{~Hz}, \mathrm{H}-6), 4.94\left(2 \mathrm{H}, \mathrm{d}, \mathrm{J}=2.5 \mathrm{~Hz}, \mathrm{H}-1^{\prime \prime}\right), 3.88\left(3 \mathrm{H}, \mathrm{s}, 3^{\prime}-\mathrm{OCH}_{3}\right), 3.85\left(3 \mathrm{H}, \mathrm{s}, 4^{\prime}-\right.$ $\left.\mathrm{OCH}_{3}\right), 3.66\left(1 \mathrm{H}, \mathrm{t}, \mathrm{J}=2.4 \mathrm{~Hz}, \mathrm{H}-3{ }^{\prime \prime}\right) .{ }^{13} \mathrm{C}$ NMR $\left(\mathrm{DMSO}-\mathrm{d}_{6}, 120 \mathrm{MHz}\right) \delta: 182.3(\mathrm{C} 4), 164.0$ (C2), 163.2 (C7), 161.3 (C5), $157.3(\mathrm{C} 8 \mathrm{a}), 152.5\left(\mathrm{C} 4^{\prime}\right), 149.2\left(\mathrm{C}^{\prime}\right), 122.9\left(\mathrm{C1}^{\prime}\right), 120.5\left(\mathrm{C}^{\prime}\right)$, $111.9\left(\mathrm{C}^{\prime}\right), 109.6\left(\mathrm{C2}^{\prime}\right), 105.3(\mathrm{C} 4 \mathrm{a}), 104.3(\mathrm{C} 3), 98.8(\mathrm{C} 6), 94.0(\mathrm{C} 8), 79.2\left(\mathrm{C}^{\prime \prime}\right), 78.6\left(\mathrm{C}^{\prime \prime}\right)$, $56.4\left(\mathrm{Cl}^{\prime \prime}\right), 56.1,56.0\left(3^{\prime}-\mathrm{OCH}_{3}\right.$ and $\left.4^{\prime}-\mathrm{OCH}_{3}\right)$. HRMS $\left(\mathrm{ESI}^{+}\right) \mathrm{m} / z$ calcd for $\mathrm{C}_{20} \mathrm{H}_{17} \mathrm{O}_{6}$ $\left[\mathrm{M}+\mathrm{H}^{+}\right]$353.10196, found 353.10174.

5-hydroxy-7-(prop-2-yn-1-yloxy)-2-(3,4,5-trimethoxyphenyl)-4H-chromen-4-one (2b). Light yellow solid; Yield: 55\%; m.p.: $211-213{ }^{\circ} \mathrm{C}$ (acetone); ${ }^{1} \mathrm{H}$ NMR (DMSO- $\mathrm{d}_{6}, 300.13 \mathrm{MHz}$ ), ઈ: $12.87(1 \mathrm{H}, \mathrm{s}, \mathrm{OH}-5), 7.36\left(2 \mathrm{H}, \mathrm{s}, \mathrm{H}-2^{\prime}\right.$ and $\left.\mathrm{H}-6^{\prime}\right), 7.16(1 \mathrm{H}, \mathrm{s}, \mathrm{H}-3), 6.91(1 \mathrm{H}, \mathrm{d}$, $\mathrm{J}=2.3 \mathrm{~Hz}, \mathrm{H}-8), 6.46(1 \mathrm{H}, \mathrm{d}, \mathrm{J}=2.3 \mathrm{~Hz}, \mathrm{H}-6), 4.96\left(2 \mathrm{H}, \mathrm{d}, \mathrm{J}=2.4 \mathrm{~Hz}, \mathrm{H}-1^{\prime \prime}\right), 3.91\left(6 \mathrm{H}, \mathrm{s}, 3^{\prime}-\right.$ $\mathrm{OCH}_{3}$ and $\left.5^{\prime}-\mathrm{OCH}_{3}\right), 3.76\left(3 \mathrm{H}, \mathrm{s}, 4^{\prime}-\mathrm{OCH}_{3}\right), 3.70\left(1 \mathrm{H}, \mathrm{t}, \mathrm{J}=2.4 \mathrm{~Hz}, \mathrm{H}-3^{\prime \prime}\right)$.

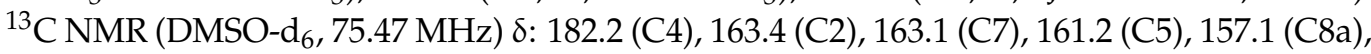
$153.3\left(\mathrm{C}^{\prime}\right.$ and $\left.\mathrm{C}^{\prime}\right), 140.9\left(\mathrm{C} 4^{\prime}\right), 125.8\left(\mathrm{C}^{\prime}\right), 105.3(\mathrm{C} 3), 105.2(\mathrm{C} 4 \mathrm{a}), 104.2\left(\mathrm{C}^{\prime}\right.$ and $\left.\mathrm{C}^{\prime}\right)$, 98.7 (C6), $93.9(\mathrm{C} 8), 79.1\left(\mathrm{C2}^{\prime \prime}\right), 78.4\left(\mathrm{C}^{\prime \prime}\right), 60.3\left(4^{\prime}-\mathrm{OCH}_{3}\right), 56.4\left(\mathrm{C1}^{\prime \prime}, 3^{\prime}-\mathrm{OCH}_{3}\right.$ and $\left.5^{\prime}-\mathrm{OCH}_{3}\right)$. HRMS $\left(\right.$ ESI $\left.^{+}\right) \mathrm{m} / z$ calcd for $\mathrm{C}_{21} \mathrm{H}_{19} \mathrm{O}_{7}\left[\mathrm{M}+\mathrm{H}^{+}\right]$383.11253, found 383.11233 .

\subsubsection{Synthesis of Flavone-Triazolyl-Glycosides $\mathbf{3 a}$ and $\mathbf{3 b}$}

To a solution of $\mathbf{2 a}(0.100 \mathrm{~g}, 0.28 \mathrm{mmol})$ or $\mathbf{2 b}(0.100 \mathrm{~g}, 0.27 \mathrm{mmol})$ and $2,3,4,6-$ tetra-O-acetyl- $\beta$-D-glucopyranosyl azide $(0.106 \mathrm{~g}, 0.28 \mathrm{mmol}$ or $0.102 \mathrm{~g}, 0.27 \mathrm{mmol})$ in THF/water solvent mixture $(2: 1 ; 30 \mathrm{~mL})$, sodium ascorbate $(0.225 \mathrm{~g}, 1.14 \mathrm{mmol}$ or $0.216 \mathrm{~g}$, $1.09 \mathrm{mmol})$ and copper(II) sulphate pentahydrate $(0.142 \mathrm{~g}, 0.57 \mathrm{mmol}$ or $0.136 \mathrm{~g}, 0.54 \mathrm{mmol})$ were added. The reaction vessel was sealed and the mixture was kept stirring and heated for $30 \mathrm{~min}$ at $70{ }^{\circ} \mathrm{C}$ under MW irradiation of $500 \mathrm{~W}$. After cooling, the reaction mixture was filtered and concentrated under reduced pressure. The water suspension was extracted with ethyl acetate $(2 \times 20 \mathrm{~mL})$, and the combined organic layers were dried over anhydrous sodium sulphate, evaporated under reduced pressure, and then purified by crystallization in acetone.

( $2 R, 3 R, 4 S, 5 R, 6 R)-2$-(acetoxymethyl)-6-(4-((2-(3,4-dimethoxyphenyl)-5-hydroxy-4-oxo-4Hchromen-7-yl)oxy)methyl)-1H-1,2,3-triazol-1-yl)tetrahydro-2H-pyran-3,4,5-triyl triacetate (3a). Light yellow solid; Yield: $82 \%$; m.p.: $143-145{ }^{\circ} \mathrm{C}$ (acetone); ${ }^{1} \mathrm{H}$ NMR (DMSO- $\mathrm{d}_{6}$, $500 \mathrm{MHz}), \delta: 12.93(1 \mathrm{H}, \mathrm{s}, \mathrm{OH}-5), 8.61\left(1 \mathrm{H}, \mathrm{s}, \mathrm{H}-3^{\prime \prime}\right), 7.71\left(1 \mathrm{H}, \mathrm{dd}, \mathrm{J}=8.5\right.$ and $\left.2.1 \mathrm{~Hz}, \mathrm{H}-6^{\prime}\right)$, $7.60\left(1 \mathrm{H}, \mathrm{d}, \mathrm{J}=2.2 \mathrm{~Hz}, \mathrm{H}-2^{\prime}\right), 7.15\left(1 \mathrm{H}, \mathrm{d}, \mathrm{J}=8.7 \mathrm{~Hz}, \mathrm{H}-5^{\prime}\right), 7.05(1 \mathrm{H}, \mathrm{s}, \mathrm{H}-3), 6.94(1 \mathrm{H}, \mathrm{d}$, $\mathrm{J}=2.2 \mathrm{~Hz}, \mathrm{H}-8), 6.47(1 \mathrm{H}, \mathrm{d}, \mathrm{J}=2.2 \mathrm{~Hz}, \mathrm{H}-6), 6.39\left(1 \mathrm{H}, \mathrm{d}, \mathrm{J}=9.2 \mathrm{~Hz}, \mathrm{H}-1^{\prime \prime \prime}\right), 5.68(1 \mathrm{H}, \mathrm{t}$, $\mathrm{J}=9.4 \mathrm{~Hz}), 5.56(1 \mathrm{H}, \mathrm{t}, \mathrm{J}=9.5 \mathrm{~Hz}), 5.19(1 \mathrm{H}, \mathrm{t}, \mathrm{J}=9.8 \mathrm{~Hz})\left(\mathrm{H}-2^{\prime \prime \prime}, \mathrm{H}-3^{\prime \prime \prime}, \mathrm{H}-4^{\prime \prime \prime}\right), 5.32(2 \mathrm{H}, \mathrm{s}$, $\left.\mathrm{H}-1^{\prime \prime}\right), 4.39-4.36\left(1 \mathrm{H}, \mathrm{m}, \mathrm{H}-5^{\prime \prime \prime}\right), 4.15-4.07\left(2 \mathrm{H}, \mathrm{m}, \mathrm{H}-6^{\prime \prime \prime}\right), 3.86\left(3 \mathrm{H}, \mathrm{s}, 4^{\prime}-\mathrm{OCH}_{3}\right), 3.83(3 \mathrm{H}$, $\left.\mathrm{s}, 3^{\prime}-\mathrm{OCH}_{3}\right), 2.03,1.99,1.96,1.77\left(12 \mathrm{H}, \mathrm{s}, 2^{\prime \prime \prime}, 3^{\prime \prime \prime}, 4^{\prime \prime \prime},-\mathrm{COCH}_{3}\right) .{ }^{13} \mathrm{C}$ NMR (DMSO-d 6 , $120 \mathrm{MHz}) \delta: 182.1(\mathrm{C} 4), 170.1,169.6,169.4,168.5\left(2^{\prime \prime \prime}, 3^{\prime \prime \prime}, 4^{\prime \prime \prime}, 6^{\prime \prime \prime}-\mathrm{COCH}_{3}\right), 163.7(\mathrm{C} 2$ and C7), 161.2 (C5), 158.0 (C8a), $152.3\left(\mathrm{C}^{\prime}\right), 149.1\left(\mathrm{C}^{\prime}\right), 142.7\left(\mathrm{C}^{\prime \prime}\right), 124.0\left(\mathrm{C}^{\prime \prime}\right), 122.7\left(\mathrm{Cl}^{\prime}\right)$, $120.2\left(\mathrm{C}^{\prime}\right), 111.7\left(\mathrm{C}^{\prime}\right), 109.5\left(\mathrm{C} 2^{\prime}\right), 105.0(\mathrm{C} 3), 104.1$ (C4a), 98.7 (C6), 93.7 (C8), 83.9 (C1'”'), 73.3 (C5 $\left.{ }^{\prime \prime \prime}\right), 72.1,70.1,67.5\left(\mathrm{C}^{\prime \prime \prime}, \mathrm{C}^{\prime \prime \prime}, \mathrm{C} 4^{\prime \prime \prime}\right), 61.8\left(\mathrm{C}^{\prime \prime \prime}\right), 61.7\left(\mathrm{C}^{\prime \prime}\right), 55.9,55.8\left(3^{\prime}-\mathrm{OCH}_{3}\right.$ and $\left.4^{\prime}-\mathrm{OCH}_{3}\right), 20.5,20.4,20.3,19.9\left(2^{\prime \prime \prime}, 3^{\prime \prime \prime}, 4^{\prime \prime \prime}, 6^{\prime \prime \prime}-\mathrm{COCH}_{3}\right)$. HRMS $\left(\mathrm{ESI}^{+}\right) \mathrm{m} / z$ calcd for $\mathrm{C}_{34} \mathrm{H}_{36} \mathrm{~N}_{3} \mathrm{O}_{15}\left[\mathrm{M}+\mathrm{H}^{+}\right]$726.21409, found 726.21380.

(2R,3R,4S,5R,6R)-2-(acetoxymethyl)-6-(4-(((5-hydroxy-4-oxo-2-(3,4,5-trimethoxyphenyl)-4Hchromen-7-yl)oxy)methyl)-1H-1,2,3-triazol-1-yl)tetrahydro-2H-pyran-3,4,5-triyl triacetate (3b). Yellow solid; Yield: 79\%; m.p.: $169-171^{\circ} \mathrm{C}$ (acetone); ${ }^{1} \mathrm{H}$ NMR (DMSO-d $6,300.13 \mathrm{MHz}$ ),

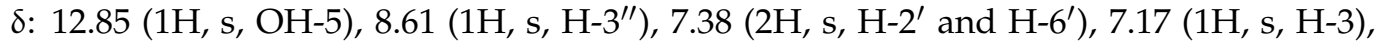
$7.00(1 \mathrm{H}, \mathrm{d}, \mathrm{J}=2.2 \mathrm{~Hz}, \mathrm{H}-8), 6.49(1 \mathrm{H}, \mathrm{d}, \mathrm{J}=2.2 \mathrm{~Hz}, \mathrm{H}-6), 6.39\left(1 \mathrm{H}, \mathrm{d}, \mathrm{J}=9.1 \mathrm{~Hz}, \mathrm{H}-\mathrm{-}^{\prime \prime \prime}\right)$, $5.68(1 \mathrm{H}, \mathrm{t}, \mathrm{J}=9.3 \mathrm{~Hz}), 5.56(1 \mathrm{H}, \mathrm{t}, \mathrm{J}=9.4 \mathrm{~Hz}), 5.19(1 \mathrm{H}, \mathrm{t}, \mathrm{J}=9.7 \mathrm{~Hz})\left(\mathrm{H}-2^{\prime \prime \prime}, \mathrm{H}-3^{\prime \prime \prime}, \mathrm{H}-4^{\prime \prime \prime}\right)$, $5.33\left(2 \mathrm{H}, \mathrm{s}, \mathrm{H}-1^{\prime \prime}\right), 4.40-4.36\left(1 \mathrm{H}, \mathrm{m}, \mathrm{H}-5^{\prime \prime \prime}\right), 4.17-4.06\left(2 \mathrm{H}, \mathrm{m}, \mathrm{H}-6^{\prime \prime \prime}\right), 3.91\left(6 \mathrm{H}, \mathrm{s}, 3^{\prime}-\mathrm{OCH}_{3}\right.$ and $\left.5^{\prime}-\mathrm{OCH}_{3}\right), 3.76\left(3 \mathrm{H}, \mathrm{s}, 4^{\prime}-\mathrm{OCH}_{3}\right), 2.03,2.00,1.96,1.77\left(12 \mathrm{H}, \mathrm{s}, 2^{\prime \prime \prime}, 3^{\prime \prime \prime}, 4^{\prime \prime \prime}, 6^{\prime \prime \prime}-\mathrm{COCH}_{3}\right)$. ${ }^{13} \mathrm{C}$ NMR (DMSO-d $\left.6,75.47 \mathrm{MHz}\right) \delta: 182.2(\mathrm{C} 4), 170.1,169.6,169.4,168.5\left(2^{\prime \prime \prime}, 3^{\prime \prime \prime}, 4^{\prime \prime \prime}\right.$, $\left.6^{\prime \prime \prime}-\mathrm{COCH}_{3}\right), 163.8(\mathrm{C} 7), 163.4(\mathrm{C} 2), 161.2(\mathrm{C} 5), 157.3(\mathrm{C} 8 \mathrm{a}), 153.3\left(\mathrm{C}^{\prime}\right.$ and $\left.\mathrm{C}^{\prime}\right), 142.7\left(\mathrm{C}^{\prime \prime}\right)$, $140.9\left(\mathrm{C}^{\prime}\right), 125.8\left(\mathrm{C}^{\prime}\right), 123.9\left(\mathrm{C}^{\prime \prime}\right), 105.1(\mathrm{C} 3$ and $\mathrm{C} 4 \mathrm{a}), 104.2\left(\mathrm{C}^{\prime}\right.$ and $\left.\mathrm{C}^{\prime}\right), 98.7(\mathrm{C} 6)$, 
93.9 (C8), $83.9\left(\mathrm{C} 1^{\prime \prime \prime}\right), 73.3\left(\mathrm{C}^{\prime \prime \prime}\right), 72.1,70.1,67.5\left(\mathrm{C} 2^{\prime \prime \prime}, \mathrm{C} 3^{\prime \prime \prime}, \mathrm{C} 4^{\prime \prime \prime}\right), 61.8\left(\mathrm{C}^{\prime \prime}\right.$ and $\left.\mathrm{C} 6^{\prime \prime \prime}\right)$, $60.3\left(4^{\prime}-\mathrm{OCH}_{3}\right), 56.3\left(3^{\prime}-\mathrm{OCH}_{3}\right.$ and $\left.5^{\prime}-\mathrm{OCH}_{3}\right), 20.5,20.4,20.3,19.9\left(2^{\prime \prime \prime}, 3^{\prime \prime \prime}, 4^{\prime \prime \prime}, 6^{\prime \prime \prime}-\mathrm{COCH}_{3}\right)$. HRMS $\left(\right.$ ESI $\left.^{+}\right) \mathrm{m} / z$ calcd for $\mathrm{C}_{35} \mathrm{H}_{38} \mathrm{~N}_{3} \mathrm{O}_{16}\left[\mathrm{M}+\mathrm{H}^{+}\right]$756.22466, found 756.22445.

\subsubsection{Synthesis of Flavone-Triazolyl-Glycosides $\mathbf{4 a}$ and $\mathbf{4 b}$}

To a solution of $2 \mathbf{a}(0.090 \mathrm{~g}, 0.26 \mathrm{mmol})$ or $\mathbf{2 b}(0.100 \mathrm{~g}, 0.26 \mathrm{mmol})$ and 2-azidoethyl2,3,4,6-tetra-O-acetyl- $\beta$-D-glucopyranoside $(0.109 \mathrm{~g}, 0.26 \mathrm{mmol})$ in tetrahydrofuran/water solvent mixture $(2: 1 ; 30 \mathrm{~mL})$, sodium ascorbate $(0.207 \mathrm{~g}, 1.05 \mathrm{mmol})$ and copper(II) sulphate pentahydrate $(0.131 \mathrm{~g}, 0.52 \mathrm{mmol})$ were added. The reaction vessel was sealed and the mixture was kept stirring and heated for $30 \mathrm{~min}$ at $70{ }^{\circ} \mathrm{C}$ under MW irradiation of $500 \mathrm{~W}$. After cooling, the reaction mixture was filtered and concentrated under reduced pressure. The water suspension was extracted with ethyl acetate $(2 \times 20 \mathrm{~mL})$, and the combined organic layers were dried over anhydrous sodium sulphate, evaporated under reduced pressure, and then purified by crystallization in ethyl acetate/n-hexane (4a) or by flash column chromatography $\left(\mathrm{SiO}_{2} ; \mathrm{n}\right.$-hexane: ethyl acetate, 3:7) $(4 \mathbf{b})$.

$(2 R, 3 R, 4 S, 5 R, 6 R)-2-(a c e t o x y m e t h y l)-6-(2-(4-(((2-(3,4-d i m e t h o x y p h e n y l)-5-h y d r o x y-4-o x o-$ 4H-chromen-7-yl)oxy)methyl)-1H-1,2,3-triazol-1-yl)ethoxy)tetrahydro-2H-pyran-3,4,5-triyl triacetate (4a). Light brown solid; Yield: $60 \%$; m.p.: $99-100{ }^{\circ} \mathrm{C}$ (n-hexane: ethyl acetate); ${ }^{1} \mathrm{H}$ NMR (DMSO-d $\left.6,300.13 \mathrm{MHz}\right), 8: 12.94(1 \mathrm{H}, \mathrm{s}, \mathrm{OH}-5), 8.15\left(1 \mathrm{H}, \mathrm{s}, \mathrm{H}-3^{\prime \prime}\right), 7.72(1 \mathrm{H}, \mathrm{dd}$, $\left.\mathrm{J}=8.5,1.8 \mathrm{~Hz}, \mathrm{H}-6^{\prime}\right), 7.59\left(1 \mathrm{H}, \mathrm{d}, \mathrm{J}=1.9 \mathrm{~Hz}, \mathrm{H}-2^{\prime}\right), 7.14\left(1 \mathrm{H}, \mathrm{d}, \mathrm{J}=8.6 \mathrm{~Hz}, \mathrm{H}-5^{\prime}\right), 7.05(1 \mathrm{H}, \mathrm{s}$, H-3), $6.96(1 \mathrm{H}, \mathrm{d}, \mathrm{J}=2.1 \mathrm{~Hz}, \mathrm{H}-8), 6.47(1 \mathrm{H}, \mathrm{d}, \mathrm{J}=2.1 \mathrm{~Hz}, \mathrm{H}-6), 5.28\left(2 \mathrm{H}, \mathrm{s}, \mathrm{H}-1^{\prime \prime}\right), 5.23(1 \mathrm{H}, \mathrm{t}$, $\mathrm{J}=9.6 \mathrm{~Hz}), 4.90(1 \mathrm{H}, \mathrm{t}, \mathrm{J}=9.7 \mathrm{~Hz}), 4.77-4.71(1 \mathrm{H}, \mathrm{m})\left(\mathrm{H}-2^{\prime \prime \prime \prime}, \mathrm{H}-3^{\prime \prime \prime \prime}, \mathrm{H}-4^{\prime \prime \prime \prime}\right), 4.72(1 \mathrm{H}, \mathrm{d}$, $\left.\mathrm{J}=8.1 \mathrm{~Hz}, \mathrm{H}-1^{\prime \prime \prime \prime \prime}\right), 4.60-4.57\left(2 \mathrm{H}, \mathrm{m}, \mathrm{H}-6^{\prime \prime \prime \prime}\right), 4.19-4.01\left(5 \mathrm{H}, \mathrm{m}, \mathrm{H}-1^{\prime \prime \prime}, \mathrm{H}-2^{\prime \prime \prime}, \mathrm{H}-5^{\prime \prime \prime \prime \prime}\right)$, $3.89\left(3 \mathrm{H}, \mathrm{s}, 3^{\prime}-\mathrm{OCH}_{3}\right), 3.86\left(3 \mathrm{H}, \mathrm{s}, 4^{\prime}-\mathrm{OCH}_{3}\right), 2.02,1.98,1.92,1.89\left(12 \mathrm{H}, \mathrm{s}, 2^{\prime \prime \prime \prime}, 3^{\prime \prime \prime \prime}\right.$, $4^{\prime \prime \prime \prime}, 6^{\prime \prime \prime \prime}-\mathrm{COCH}_{3}$ ). ${ }^{13} \mathrm{C}$ NMR (DMSO-d $6,75.47 \mathrm{MHz}$ ) $\delta: 182.1$ (C4), 170.1, 169.6, 169.3, $169.0\left(2^{\prime \prime \prime \prime \prime}, 3^{\prime \prime \prime \prime}, 4^{\prime \prime \prime \prime}, 6^{\prime \prime \prime \prime}-\mathrm{COCH}_{3}\right), 163.9$ (C7), 163.7 (C2), 161.2 (C5), 157.2 (C8a), 152.3 (C4'), $149.0\left(\mathrm{C}^{\prime}\right), 141.7\left(\mathrm{C2}^{\prime \prime}\right), 125.2\left(\mathrm{C}^{\prime \prime}\right), 122.8\left(\mathrm{C}^{\prime}\right), 120.2\left(\mathrm{C}^{\prime}\right), 111.7\left(\mathrm{C}^{\prime}\right), 109.5\left(\mathrm{C}^{\prime}\right)$,

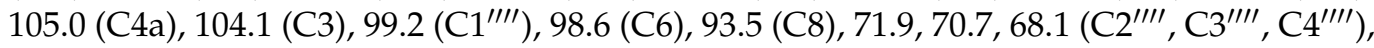
70.6, 67.4, $61.7\left(\mathrm{C}^{\prime \prime \prime}, \mathrm{C} 2^{\prime \prime \prime}, \mathrm{C}^{\prime \prime \prime \prime \prime}\right), 61.9\left(\mathrm{C}^{\prime \prime}\right), 55.9,55.8\left(3^{\prime}-\mathrm{OCH}_{3}\right.$ and $\left.4^{\prime}-\mathrm{OCH}_{3}\right), 49.4\left(\mathrm{C}^{\prime \prime \prime \prime \prime}\right)$, 20.5, 20.4, 20.3, $20.3\left(2^{\prime \prime \prime \prime}, 3^{\prime \prime \prime \prime}, 4^{\prime \prime \prime \prime \prime}, 6^{\prime \prime \prime \prime \prime}-\mathrm{COCH}_{3}\right)$. HRMS $\left(\mathrm{ESI}^{+}\right) \mathrm{m} / z$ calcd for $\mathrm{C}_{36} \mathrm{H}_{40} \mathrm{~N}_{3} \mathrm{O}_{16}$ $\left[\mathrm{M}+\mathrm{H}^{+}\right]$770.24031, found 770. 23792.

(2R,3R,4S,5R,6R)-2-(acetoxymethyl)-6-(2-(4-(((5-hydroxy-4-oxo-2-(3,4,5-trimethoxyphenyl)-4Hchromen-7-yl)oxy)methyl)-1H-1,2,3-triazol-1-yl)ethoxy)tetrahydro-2H-pyran-3,4,5-triyl triacetate (4b). Light yellow solid; Yield: $49 \%$; m.p.: $96-98{ }^{\circ} \mathrm{C}$ (n-hexane: ethyl acetate); ${ }^{1} \mathrm{H}$ NMR (DMSO-d $\left.\mathrm{d}_{6}, 300.13 \mathrm{MHz}\right), \delta: 12.86(1 \mathrm{H}, \mathrm{s}, \mathrm{OH}-5), 8.15\left(1 \mathrm{H}, \mathrm{s}, \mathrm{H}-3^{\prime \prime}\right), 7.38(2 \mathrm{H}, \mathrm{s}$, H-2' and H-6' $), 7.17(1 \mathrm{H}, \mathrm{s}, \mathrm{H}-3), 7.02(1 \mathrm{H}, \mathrm{d}, \mathrm{J}=2.2 \mathrm{~Hz}, \mathrm{H}-8), 6.49(1 \mathrm{H}, \mathrm{d}, \mathrm{J}=2.2 \mathrm{~Hz}, \mathrm{H}-6)$, $5.29\left(2 \mathrm{H}, \mathrm{s}, \mathrm{H}-1^{\prime \prime}\right), 5.23(1 \mathrm{H}, \mathrm{t}, \mathrm{J}=9.5 \mathrm{~Hz}), 4.90(1 \mathrm{H}, \mathrm{t}, \mathrm{J}=9.7 \mathrm{~Hz}), 4.74(1 \mathrm{H}, \mathrm{t}, \mathrm{J}=8.8 \mathrm{~Hz})$ $\left(\mathrm{H}-2^{\prime \prime \prime \prime}, \mathrm{H}-3^{\prime \prime \prime \prime \prime}, \mathrm{H}-4^{\prime \prime \prime \prime}\right), 4.84\left(1 \mathrm{H}, \mathrm{d}, \mathrm{J}=8.0, \mathrm{H}-1^{\prime \prime \prime \prime}\right), 4.60-4.56\left(2 \mathrm{H}, \mathrm{m}, \mathrm{H}-6^{\prime \prime \prime \prime \prime}\right), 4.21-4.01(5 \mathrm{H}$, $\mathrm{m}, \mathrm{H}-5^{\prime \prime \prime \prime}, \mathrm{H}-1^{\prime \prime \prime}$ and $\left.\mathrm{H}-2^{\prime \prime \prime}\right), 3.91\left(6 \mathrm{H}, \mathrm{s}, 3^{\prime}-\mathrm{OCH}_{3}\right.$ and $\left.5^{\prime}-\mathrm{OCH}_{3}\right), 3.76\left(3 \mathrm{H}, \mathrm{s}, 4^{\prime}-\mathrm{OCH}_{3}\right)$, $2.02,1.98,1.92,1.89\left(12 \mathrm{H}, \mathrm{s}, 2^{\prime \prime \prime \prime \prime}, 3^{\prime \prime \prime \prime}, 4^{\prime \prime \prime \prime}, 6^{\prime \prime \prime \prime}-\mathrm{COCH}_{3}\right) .{ }^{13} \mathrm{C}$ NMR (DMSO-d $\left.6,75.47 \mathrm{MHz}\right)$

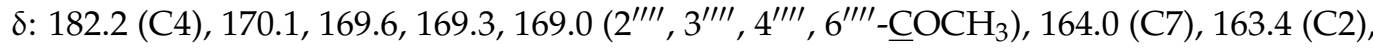
161.1 (C5), 157.3 (C8a), 153.3 (C3' and C5'), $141.6\left(\mathrm{C2}^{\prime \prime}\right), 140.9\left(\mathrm{C}^{\prime}\right), 125.8\left(\mathrm{Cl}^{\prime}\right), 125.2\left(\mathrm{C}^{\prime \prime}\right)$,

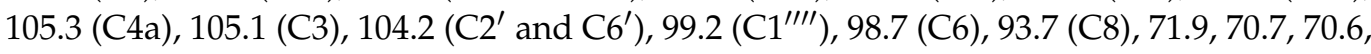
$68.1\left(\mathrm{C}^{\prime \prime \prime \prime \prime}, \mathrm{C} 3^{\prime \prime \prime \prime}, \mathrm{C} 4^{\prime \prime \prime \prime}\right.$ and $\left.\mathrm{C}^{\prime \prime \prime \prime}\right), 67.4,61.7\left(\mathrm{C}^{\prime \prime \prime \prime}, \mathrm{C}^{\prime \prime \prime \prime}\right), 62.0\left(\mathrm{C}^{\prime \prime}\right), 60.3\left(4^{\prime}-\mathrm{OCH}_{3}\right), 56.4\left(3^{\prime}\right.$ and $\left.5^{\prime}-\mathrm{OCH}_{3}\right), 49.4\left(\mathrm{C}^{\prime \prime \prime \prime \prime}\right), 20.5,20.4,20.3,20.3\left(2^{\prime \prime \prime \prime}, 3^{\prime \prime \prime \prime}, 4^{\prime \prime \prime \prime}, 6^{\prime \prime \prime \prime}-\mathrm{COCH}_{3}\right)$. HRMS $\left(\mathrm{ESI}^{+}\right)$ $m / z$ calcd for $\mathrm{C}_{37} \mathrm{H}_{42} \mathrm{~N}_{3} \mathrm{O}_{17}\left[\mathrm{M}+\mathrm{H}^{+}\right]$800.25087, found 800.24829.

\subsubsection{Synthesis of Propargyloxyacetophenone 5}

To a solution of 2,4-dihydroxyacetophenone $(1.00 \mathrm{~g}, 6.57 \mathrm{mmol})$ and potassium carbonate $(0.91 \mathrm{~g}, 6.57 \mathrm{mmol})$ in anhydrous acetone $(20 \mathrm{~mL})$, propargyl bromide solution, $80 \mathrm{wt} . \%$ in toluene $(0.73 \mathrm{~mL}, 6.57 \mathrm{mmol})$ was added. The mixture was refluxed at $60{ }^{\circ} \mathrm{C}$ during $3 \mathrm{~h}$. Then, the reaction mixture was filtered, evaporated under reduced pressure and purified by flash column chromatography $\left(\mathrm{SiO}_{2} ; \mathrm{n}\right.$-hexane: ethyl acetate), 9:1), giving rise to 5 with 
$76 \%$ yield. The structure elucidation of compound 5 was established by ${ }^{1} \mathrm{H}$ and ${ }^{13} \mathrm{C}$ NMR techniques and data were in accordance with previously reported results [23].

\subsubsection{Synthesis of Propargyloxychalcones $\mathbf{6 a}$ and $\mathbf{6 b}$}

To a solution of $5(0.350 \mathrm{~g}, 1.84 \mathrm{mmol})$ in methanol $(20 \mathrm{~mL})$ was added a solution of $40 \%$ $\mathrm{NaOH}$ in methanol, until $\mathrm{pH} 14$, under stirring. Afterwards, 3,4-dimethoxybenzaldehyde (0.612 g, $3.68 \mathrm{mmol})$ or 3,4,5-trimethoxybenzaldehyde $(0.772 \mathrm{~g}$, $3.68 \mathrm{mmol})$ was slowly added to the reaction mixture. The reaction was submitted to MW irradiation at $180 \mathrm{~W}$ at $70{ }^{\circ} \mathrm{C}$ for $4 \mathrm{~h}$. After, a solution of $10 \% \mathrm{HCl}$ was added until $\mathrm{pH} 5$, and the obtained solid was filtered, washed with water, and purified by crystallization with methanol, giving rise to chalcone $\mathbf{6 a}$ and $\mathbf{6} \mathbf{b}$ with $41 \%$ and $43 \%$ yield, respectively. The structure elucidation of compounds $\mathbf{6 a}$ and $\mathbf{6} \mathbf{b}$ was established by ${ }^{1} \mathrm{H}$ and ${ }^{13} \mathrm{C}$ NMR techniques and data were in accordance with previously reported results [23].

\subsubsection{Synthesis of Chalcone-Triazolyl-Glycosides $7 \mathbf{a}$ and $7 \mathbf{b}$}

To a solution of $6 \mathbf{a}(0.140 \mathrm{~g}, 0.41 \mathrm{mmol})$ or $6 \mathbf{b}(0.200 \mathrm{~g}, 0.54 \mathrm{mmol})$ and 2,3,4,6-tetra$O$-acetyl- $\beta$-D-glucopyranosyl azide $(0.309 \mathrm{~g}, 0.82 \mathrm{mmol}$ or $0.405 \mathrm{~g}, 1.09 \mathrm{mmol})$ in tetrahydrofuran (THF)/water solvent mixture $(2: 1 ; 30 \mathrm{~mL})$, sodium ascorbate $(0.328 \mathrm{~g}, 1.66 \mathrm{mmol}$ or $0.430 \mathrm{~g}, 2.17 \mathrm{mmol})$ and copper(II) sulphate pentahydrate $(0.207 \mathrm{~g}, 0.83 \mathrm{mmol}$ or 0.271 $\mathrm{g}, 1.09 \mathrm{mmol}$ ) were added. The reaction mixture was heated for $1 \mathrm{~h}$ at $70{ }^{\circ} \mathrm{C}$ under MW irradiation of $250 \mathrm{~W}$ with agitation. After cooling, the reaction mixture was filtered and concentrated under reduced pressure. The water suspension was extracted with ethyl acetate $(2 \times 20 \mathrm{~mL})$ and the combined organic layers were washed with water $(1 \times 20 \mathrm{~mL})$, dried over anhydrous sodium sulphate, evaporated under reduced pressure, and then purified by crystallization with methanol.

(2R,3R,4S,5R,6R)-2-(acetoxymethyl)-6-(4-((4-(€-3-(3,4-dimethoxyphenyl)acryloyl)-3- hydroxyphenoxy)methyl)-1H-1,2,3-triazol-1-yl)tetrahydro-2H-pyran-3,4,5-triyl triacetate (7a). Yellow solid; yield: $51 \%$; m.p.: $169-171{ }^{\circ} \mathrm{C}$ (methanol); ${ }^{1} \mathrm{H}$ NMR $\left(\mathrm{CDCl}_{3}, 300.13 \mathrm{MHz}\right)$,

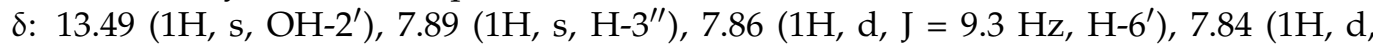
$\mathrm{J}=15.5 \mathrm{~Hz}, \mathrm{H}-\beta), 7.43(1 \mathrm{H}, \mathrm{d}, \mathrm{J}=15.5 \mathrm{~Hz}, \mathrm{H}-\alpha), 7.26-7.22(1 \mathrm{H}, \mathrm{m}, \mathrm{H}-6), 7.16(1 \mathrm{H}, \mathrm{d}$, $\mathrm{J}=1.9 \mathrm{~Hz}, \mathrm{H}-2), 6.90(1 \mathrm{H}, \mathrm{d}, \mathrm{J}=8.3 \mathrm{~Hz}, \mathrm{H}-5), 6.58-6.55\left(2 \mathrm{H}, \mathrm{m}, \mathrm{H}-3^{\prime}\right.$ and $\left.\mathrm{H}-5^{\prime}\right), 5.90(1 \mathrm{H}$, $\left.\mathrm{d}, \mathrm{J}=9.2 \mathrm{~Hz}, \mathrm{H}-1^{\prime \prime \prime}\right), 5.48-5.38(2 \mathrm{H}, \mathrm{m}), 5.27-5.18(1 \mathrm{H}, \mathrm{m})\left(\mathrm{H}-2^{\prime \prime \prime}, \mathrm{H}-3^{\prime \prime \prime}, \mathrm{H}-4^{\prime \prime \prime}\right), 5.24(2 \mathrm{H}, \mathrm{s}$, $\left.\mathrm{H}-1^{\prime \prime}\right), 4.33-4.11\left(2 \mathrm{H}, \mathrm{m}, \mathrm{H}-6^{\prime \prime \prime}\right), 4.04-3.98\left(1 \mathrm{H}, \mathrm{m}, \mathrm{H}-5^{\prime \prime \prime}\right), 3.96\left(3 \mathrm{H}, \mathrm{s}, 3-\mathrm{OCH}_{3}\right), 3.93(3 \mathrm{H}, \mathrm{s}$,

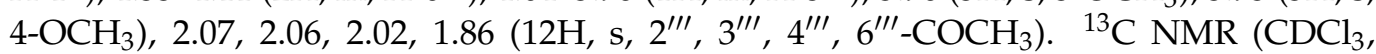
$75.47 \mathrm{MHz})$ 8: $192.0(\mathrm{CO}), 170.6,170.0,169.5,169.1\left(2^{\prime \prime \prime}, 3^{\prime \prime \prime}, 4^{\prime \prime \prime}, 6^{\prime \prime \prime}-\mathrm{COCH}_{3}\right), 166.6$ (C2'), 164.5 (C4'), 151.8 (C3), 149.4 (C4) 145.0 (C 3$), 144.1$ (C2' $), 131.4\left(\mathrm{C}^{\prime}\right), 127.8$ (C1), 123.6 (C6), $121.5\left(\mathrm{C}^{\prime \prime}\right), 118.0(\mathrm{C} \alpha), 114.7\left(\mathrm{C1}^{\prime}\right), 111.3(\mathrm{C} 5), 110.3(\mathrm{C} 2), 107.9\left(\mathrm{C}^{\prime}\right), 102.3\left(\mathrm{C}^{\prime}\right)$, $85.9\left(\mathrm{C} 1^{\prime \prime \prime}\right), 75.3\left(\mathrm{C}^{\prime \prime \prime}\right), 72.7,70.4,67.8\left(\mathrm{C} 2^{\prime \prime \prime}, \mathrm{C}^{\prime \prime \prime}, \mathrm{C}^{\prime \prime \prime}\right), 62.0\left(\mathrm{C}^{\prime \prime}\right), 61.6\left(\mathrm{C}^{\prime \prime \prime}\right), 56.2\left(3-\mathrm{OCH}_{3}\right)$, $56.1\left(4-\mathrm{OCH}_{3}\right), 20.8,20.7,20.6,20.3\left(2^{\prime \prime \prime}, 3^{\prime \prime \prime}, 4^{\prime \prime \prime}, 6^{\prime \prime \prime}-\mathrm{COCH}_{3}\right)$. HRMS $\left(\mathrm{ESI}^{+}\right) \mathrm{m} / z$ calcd for $\mathrm{C}_{34} \mathrm{H}_{38} \mathrm{~N}_{3} \mathrm{O}_{14}\left[\mathrm{M}+\mathrm{H}^{+}\right]$712.23483, found 712.23337.

$(2 R, 3 R, 4 S, 5 R, 6 R)$-2-(acetoxymethyl)-6-(4-((3-hydroxy-4-((E)-3-(3,4,5-trimethoxyphenyl) acryloyl)phenoxy)methyl)-1H-1,2,3-triazol-1-yl)tetrahydro-2H-pyran-3,4,5-triyl triacetate (7b). Yellow solid; yield: $57 \%$; m.p.: $127-128^{\circ} \mathrm{C}$ (quamarnol); ${ }^{1} \mathrm{H}$ NMR $\left(\mathrm{CDCl}_{3}, 300.13 \mathrm{MHz}\right)$,

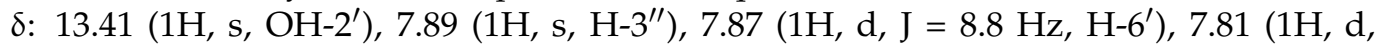
$\mathrm{J}=15.4 \mathrm{~Hz}, \mathrm{H}-\beta), 7.45(1 \mathrm{H}, \mathrm{d}, \mathrm{J}=15.4 \mathrm{~Hz}, \mathrm{H}-\alpha), 6.87(2 \mathrm{H}, \mathrm{s}, \mathrm{H}-2$ and $\mathrm{H}-6), 6.60-6.56(2 \mathrm{H}, \mathrm{m}$, $\mathrm{H}-3^{\prime}$ and $\left.\mathrm{H}-5^{\prime}\right), 5.91-5.88\left(1 \mathrm{H}, \mathrm{m}, \mathrm{H}-1^{\prime \prime \prime}\right), 5.48-5.39(2 \mathrm{H}, \mathrm{m}), 5.27-5.21(1 \mathrm{H}, \mathrm{m})\left(\mathrm{H}-2^{\prime \prime \prime}, \mathrm{H}-3^{\prime \prime \prime}\right.$, $\left.\mathrm{H}-4^{\prime \prime \prime}\right), 5.25\left(2 \mathrm{H}, \mathrm{s}, \mathrm{H}-1^{\prime \prime}\right), 4.34-4.13\left(2 \mathrm{H}, \mathrm{m}, \mathrm{H}-6^{\prime \prime \prime}\right), 4.03-4.00\left(1 \mathrm{H}, \mathrm{m}, \mathrm{H}-5^{\prime \prime \prime}\right), 3.93(6 \mathrm{H}, \mathrm{s}$, $3-\mathrm{OCH}_{3}$ and $\left.5-\mathrm{OCH}_{3}\right), 3.91\left(3 \mathrm{H}, \mathrm{s}, 4-\mathrm{OCH}_{3}\right), 2.08,2.07,2.02,1.87\left(12 \mathrm{H}, \mathrm{s}, 2^{\prime \prime \prime}, 3^{\prime \prime \prime}, 4^{\prime \prime \prime}, 6^{\prime \prime \prime}-\right.$ $\left.\mathrm{COCH}_{3}\right) .{ }^{13} \mathrm{C} \mathrm{NMR}\left(\mathrm{CDCl}_{3}, 75.47 \mathrm{MHz}\right) \delta: 191.9(\mathrm{CO}), 170.6,170.0,169.5,169.1\left(2^{\prime \prime \prime}, 3^{\prime \prime \prime}, 4^{\prime \prime \prime}\right.$, $\left.6^{\prime \prime \prime}-\mathrm{COCH}_{3}\right), 166.6\left(\mathrm{C}^{\prime}\right), 164.6\left(\mathrm{C}^{\prime}\right), 153.7(\mathrm{C} 3$ and $\mathrm{C} 5), 145.0(\mathrm{C} \beta), 144.1\left(\mathrm{C}^{\prime \prime}\right), 140.8(\mathrm{C} 4)$, $131.5\left(\mathrm{C}^{\prime}\right), 130.3(\mathrm{C} 1), 121.5\left(\mathrm{C}^{\prime \prime}\right), 119.5(\mathrm{C} \alpha), 114.7\left(\mathrm{C}^{\prime}\right), 108.0\left(\mathrm{C}^{\prime}\right), 105.9(\mathrm{C} 2$ and $\mathrm{C} 6)$, $102.3\left(\mathrm{C}^{\prime}\right), 86.0\left(\mathrm{C}^{\prime \prime \prime}\right), 75.4\left(\mathrm{C}^{\prime \prime \prime}\right), 72.7,70.4,67.8\left(\mathrm{C}^{\prime \prime \prime}, \mathrm{C}^{\prime \prime \prime}, \mathrm{C} 4^{\prime \prime \prime}\right), 62.1\left(\mathrm{C}^{\prime \prime}\right), 61.6\left(\mathrm{C}^{\prime \prime \prime}\right)$, 
61.2 (4-- $\left.\mathrm{OCH}_{3}\right), 56.4\left(3-\mathrm{OCH}_{3}\right.$ and 5- $\left.-\mathrm{OCH}_{3}\right), 20.8,20.7,20.6,20.3\left(2^{\prime \prime \prime}, 3^{\prime \prime \prime}, 4^{\prime \prime \prime}, 6^{\prime \prime \prime}-\mathrm{COCH}_{3}\right)$. HRMS $\left(\right.$ ESI $^{+}$) $m / z$ calcd for $\mathrm{C}_{35} \mathrm{H}_{40} \mathrm{~N}_{3} \mathrm{O}_{15}\left[\mathrm{M}+\mathrm{H}^{+}\right]$742.24539, found 742.24366.

\subsubsection{Synthesis of Chalcone-Triazolyl-Glycosides $\mathbf{8} \mathbf{a}$ and $\mathbf{8 b}$}

To a solution of $6 \mathbf{a}(0.050 \mathrm{~g}, 0.15 \mathrm{mmol})$ or $6 \mathbf{b}(0.2500 \mathrm{~g}, 0.68 \mathrm{mmol})$ and 2-azidoethyl2,3,4,6-tetra-O-acetyl- $\beta$-D-glucopyranoside $(0.123 \mathrm{~g}, 0.30 \mathrm{mmol}$ or $0.566 \mathrm{~g}, 1.36 \mathrm{mmol})$ in THF/water solvent mixture $(2: 1 ; 30 \mathrm{~mL})$, sodium ascorbate $(0.117 \mathrm{~g}, 0.59 \mathrm{mmol}$ or $0.538 \mathrm{~g}$, $2.71 \mathrm{mmol})$ and copper(II) sulphate pentahydrate $(0.074 \mathrm{~g}, 0.30 \mathrm{mmol}$ or $0.339 \mathrm{~g}, 1.36 \mathrm{mmol})$ were added. The reaction mixture was heated for $1 \mathrm{~h}$ at $70{ }^{\circ} \mathrm{C}$ under MW irradiation of $250 \mathrm{~W}$ with agitation. After cooling, the reaction mixture was filtered and the THF in the filtrate was evaporated under reduced pressure. Then, the water suspension was extracted with ethyl acetate $(2 \times 20 \mathrm{~mL})$ and the combined organic layers were washed with water $(1 \times 20 \mathrm{~mL})$, dried over anhydrous sodium sulphate, concentrated under reduced pressure, and then purified by preparative TLC $\left(\mathrm{SiO}_{2} ;\right.$ n-hexane: ethyl acetate, 2:8) (8a) or flash column chromatography $\left(\mathrm{SiO}_{2} ; \mathrm{n}\right.$-hexane: ethyl acetate, 5:5) $(\mathbf{8 b})$.

$(2 R, 3 R, 4 S, 5 R, 6 R)-2$-(acetoxymethyl)-6-(2-(4-((4-((E)-3-(3,4-dimethoxyphenyl)acryloyl)-3hydroxyphenoxy)methyl)-1H-1,2,3-triazol-1-yl)ethoxy)tetrahydro-2H-pyran-3,4,5-triyl triacetate (8a). Yellow solid; yield: $65 \%$; m.p.: $77-79{ }^{\circ} \mathrm{C}$ (n-hexane: ethyl acetate); ${ }^{1} \mathrm{H}$ NMR $\left(\mathrm{CDCl}_{3}, 300.13 \mathrm{MHz}\right), \delta: 13.49\left(1 \mathrm{H}, \mathrm{s}, \mathrm{OH}-2^{\prime}\right), 7.87\left(1 \mathrm{H}, \mathrm{d}, \mathrm{J}=9.7 \mathrm{~Hz}, \mathrm{H}-6^{\prime}\right), 7.85(1 \mathrm{H}, \mathrm{d}$, $\mathrm{J}=15.4 \mathrm{~Hz}, \mathrm{H}-\beta), 7.73\left(1 \mathrm{H}, \mathrm{s}, \mathrm{H}-3^{\prime \prime}\right), 7.44(1 \mathrm{H}, \mathrm{d}, \mathrm{J}=15.4 \mathrm{~Hz}, \mathrm{H}-\alpha), 7.25(1 \mathrm{H}, \mathrm{dd}, \mathrm{J}=8.1$, 1.8, H-6), $7.16(1 \mathrm{H}, \mathrm{d}, \mathrm{J}=1.8, \mathrm{H}-2), 6.91(1 \mathrm{H}, \mathrm{d}, \mathrm{J}=8.4, \mathrm{H}-5), 6.60-6.56\left(2 \mathrm{H}, \mathrm{m}, \mathrm{H}-3^{\prime}\right.$ and $\left.\mathrm{H}-5^{\prime}\right), 5.23\left(2 \mathrm{H}, \mathrm{s}, \mathrm{H}-1^{\prime \prime}\right), 5.18(1 \mathrm{H}, \mathrm{t}, \mathrm{J}=9.4), 5.06(1 \mathrm{H}, \mathrm{t}, \mathrm{J}=9.6), 5.03-4.97(1 \mathrm{H}, \mathrm{m})\left(\mathrm{H}-2^{\prime \prime \prime \prime \prime}\right.$, $\left.\mathrm{H}-3^{\prime \prime \prime \prime}, \mathrm{H}-4^{\prime \prime \prime \prime}\right), 4.68-4.52\left(2 \mathrm{H}, \mathrm{m}, \mathrm{H}-6^{\prime \prime \prime \prime}\right), 4.48\left(1 \mathrm{H}, \mathrm{d}, \mathrm{J}=7.9, \mathrm{H}-1^{\prime \prime \prime \prime}\right), 4.27-4.21(2 \mathrm{H}, \mathrm{m})$, 4.15-4.10 (1H, m), 3.90-3.81 (1H, m) (H-1'"', H-2'"'), $3.96\left(3 \mathrm{H}, \mathrm{s}, 3-\mathrm{OCH}_{3}\right), 3.94(3 \mathrm{H}, \mathrm{s}$, $\left.4-\mathrm{OCH}_{3}\right), 3.72-3.66\left(1 \mathrm{H}, \mathrm{m}, \mathrm{H}-5^{\prime \prime \prime \prime}\right), 2.08,2.01,1.99,1.95\left(12 \mathrm{H}, \mathrm{s}, 2^{\prime \prime \prime \prime}, 3^{\prime \prime \prime \prime}, 4^{\prime \prime \prime \prime}\right.$, $\left.6^{\prime \prime \prime \prime \prime}-\mathrm{COCH}_{3}\right) .{ }^{13} \mathrm{C}^{\prime \prime} \mathrm{NMR}\left(\mathrm{CDCl}_{3}, 75.47 \mathrm{MHz}\right) \delta$ : $192.0(\mathrm{CO}), 170.7,170.3,169.6,169.5$ $\left(2^{\prime \prime \prime \prime \prime}, 3^{\prime \prime \prime \prime \prime}, 4^{\prime \prime \prime \prime}, 6^{\prime \prime \prime \prime}-\mathrm{COCH}_{3}\right), 166.6\left(\mathrm{C}^{\prime}\right), 164.6\left(\mathrm{C}^{\prime}\right), 151.8(\mathrm{C} 4), 149.4$ (C3) 144.9 (Cß), 143.1 (C2'), $131.5\left(\mathrm{C}^{\prime}\right), 127.9(\mathrm{C} 1), 124.6\left(\mathrm{C} 3^{\prime \prime}\right), 123.6(\mathrm{C} 6), 118.1(\mathrm{C} \alpha), 114.7\left(\mathrm{C1}^{\prime}\right), 111.3(\mathrm{C} 5)$, $110.3(\mathrm{C} 2), 107.9\left(\mathrm{C}^{\prime}\right), 102.3\left(\mathrm{C} 3^{\prime}\right), 100.6\left(\mathrm{C}^{\prime \prime \prime \prime \prime}\right), 72.1\left(\mathrm{C}^{\prime \prime \prime \prime}\right), 72.6,71.1,68.3\left(\mathrm{C} 2^{\prime \prime \prime \prime \prime}, \mathrm{C} 3^{\prime \prime \prime \prime \prime}\right.$ and $\left.\mathrm{C}^{\prime \prime \prime \prime \prime}\right), 67.8,61.8\left(\mathrm{C}^{\prime \prime \prime}\right.$ and $\left.\mathrm{C}^{\prime \prime \prime \prime}\right), 62.1\left(\mathrm{C}^{\prime \prime}\right), 56.2\left(3^{\prime}-\mathrm{OCH}_{3}\right), 56.1\left(4^{\prime}-\mathrm{OCH}_{3}\right), 50.3\left(\mathrm{C}^{\prime \prime \prime \prime \prime}\right)$, $20.9,20.7,20.7,20.7\left(2^{\prime \prime \prime \prime}, 3^{\prime \prime \prime \prime}, 4^{\prime \prime \prime \prime \prime}, 6^{\prime \prime \prime \prime}-\mathrm{COCH}_{3}\right)$. HRMS $\left(\mathrm{ESI}^{+}\right) \mathrm{m} / z$ calcd for $\mathrm{C}_{36} \mathrm{H}_{42} \mathrm{~N}_{3} \mathrm{O}_{15}$ $\left[\mathrm{M}+\mathrm{H}^{+}\right]$756.261044, found 756.26373.

$(2 R, 3 R, 4 S, 5 S, 6 S)-2-(a c e t o x y m e t h y l)-6-(2-(4-((3-h y d r o x y-4-((E)-3-(3,4,5-$ trimethoxyphenyl) acryloyl)phenoxy)methyl)-1H-1,2,3-triazol-1-yl)ethoxy)tetrahydro-2H-pyran-3,4,5-triyl triacetate (8b). Yellow solid; yield: $45 \%$; m.p.: $78-81{ }^{\circ} \mathrm{C}$ (n-hexane: ethyl acetate); ${ }^{1} \mathrm{H}$ NMR $\left(\mathrm{CDCl}_{3}, 300.13 \mathrm{MHz}\right), \delta: 13.41\left(1 \mathrm{H}, \mathrm{s}, \mathrm{OH}-2^{\prime}\right), 7.87\left(1 \mathrm{H}, \mathrm{d}, \mathrm{J}=9.8 \mathrm{~Hz}, \mathrm{H}-6^{\prime}\right), 7.81(1 \mathrm{H}, \mathrm{d}$, $\mathrm{J}=15.4 \mathrm{~Hz}, \mathrm{H}-\beta), 7.74\left(1 \mathrm{H}, \mathrm{s}, \mathrm{H}-3^{\prime \prime}\right), 7.46(1 \mathrm{H}, \mathrm{d}, \mathrm{J}=15.4 \mathrm{~Hz}, \mathrm{H}-\alpha), 6.87(2 \mathrm{H}, \mathrm{s}, \mathrm{H}-2$ and $\mathrm{H}-6), 6.61-6.57\left(2 \mathrm{H}, \mathrm{m}, \mathrm{H}-3^{\prime}\right.$ and H-5'), $5.24\left(2 \mathrm{H}, \mathrm{s}, \mathrm{H}-1^{\prime \prime}\right), 5.18(1 \mathrm{H}, \mathrm{t}, \mathrm{J}=9.4), 5.07(1 \mathrm{H}, \mathrm{t}$, $\mathrm{J}=9.6), 4.99(1 \mathrm{H}, \mathrm{t}, \mathrm{J}=8.7)\left(\mathrm{H}-2^{\prime \prime \prime \prime}, \mathrm{H}-3^{\prime \prime \prime \prime}, \mathrm{H}-4^{\prime \prime \prime \prime}\right), 4.68-4.52\left(2 \mathrm{H}, \mathrm{m}, \mathrm{H}-6^{\prime \prime \prime \prime}\right), 4.48(1 \mathrm{H}, \mathrm{d}$, $\left.\mathrm{J}=7.9, \mathrm{H}-1^{\prime \prime \prime \prime}\right), 4.28-4.21(2 \mathrm{H}, \mathrm{m}), 4.13-4.08(2 \mathrm{H}, \mathrm{m})\left(\mathrm{H}-\mathrm{1}^{\prime \prime \prime}\right.$ and $\left.\mathrm{H}-2^{\prime \prime \prime}\right), 3.93\left(3 \mathrm{H}, \mathrm{s}, 4-\mathrm{OCH}_{3}\right)$, $3.91\left(6 \mathrm{H}, \mathrm{s}, 3-\mathrm{OCH}_{3}\right.$ and $\left.5-\mathrm{OCH}_{3}\right), 3.72-3.66\left(1 \mathrm{H}, \mathrm{m}, \mathrm{H}-5^{\prime \prime \prime \prime}\right), 2.04,2.02,1.99,1.95(12 \mathrm{H}, \mathrm{s}$, $\left.2^{\prime \prime \prime \prime}, 3^{\prime \prime \prime \prime}, 4^{\prime \prime \prime \prime \prime}, 6^{\prime \prime \prime \prime \prime}-\mathrm{COCH}_{3}\right) .{ }^{13} \mathrm{C}$ NMR $\left(\mathrm{CDCl}_{3}, 75.47 \mathrm{MHz}\right) \delta: 191.9$ (CO), 170.7, 170.3, 169.6, $169.5\left(2^{\prime \prime \prime \prime \prime}, 3^{\prime \prime \prime \prime \prime}, 4^{\prime \prime \prime \prime \prime}, 6^{\prime \prime \prime \prime}-\mathrm{COCH}_{3}\right), 166.7\left(\mathrm{C}^{\prime}\right), 164.8\left(\mathrm{C}^{\prime}\right), 153.6$ (C3 and C5), $144.9(\mathrm{C} \beta)$, $143.0\left(\mathrm{C} 2^{\prime \prime}\right), 140.7(\mathrm{C} 4), 131.5\left(\mathrm{C} 6^{\prime}\right), 130.4(\mathrm{C} 1), 124.7\left(\mathrm{C}^{\prime \prime}\right), 119.6(\mathrm{C} \alpha), 114.6\left(\mathrm{C1}^{\prime}\right), 108.0\left(\mathrm{C5}^{\prime}\right)$, 105.9 (C2 and $\mathrm{C} 6), 102.3\left(\mathrm{C}^{\prime}\right), 100.6\left(\mathrm{C}^{\prime \prime \prime \prime}\right), 72.1\left(\mathrm{C}^{\prime \prime \prime \prime \prime}\right), 72.6,71.1,68.3\left(\mathrm{C} 2^{\prime \prime \prime \prime \prime}, \mathrm{C} 3^{\prime \prime \prime \prime}\right.$ and $\left.\mathrm{C}^{\prime \prime \prime \prime \prime}\right), 67.8,61.9\left(\mathrm{C}^{\prime \prime \prime \prime}\right.$ and $\left.\mathrm{C}^{\prime \prime \prime}\right), 62.1\left(\mathrm{C}^{\prime \prime}\right), 60.5\left(4-\mathrm{OCH}_{3}\right), 56.4\left(3-\mathrm{OCH}_{3}\right.$ and $\left.5-\mathrm{OCH}_{3}\right)$, $50.3\left(\mathrm{C}^{\prime \prime \prime \prime}\right), 21.2,20.9,20.7,20.7\left(2^{\prime \prime \prime \prime}, 3^{\prime \prime \prime \prime}, 4^{\prime \prime \prime \prime}, 6^{\prime \prime \prime \prime \prime}-\mathrm{COCH}_{3}\right)$. HRMS $\left(\mathrm{ESI}^{+}\right) \mathrm{m} / z$ calcd for $\mathrm{C}_{37} \mathrm{H}_{44} \mathrm{~N}_{3} \mathrm{O}_{16}\left[\mathrm{M}+\mathrm{H}^{+}\right]$786.27161, found 786.26915.

\subsubsection{Synthesis of Acetophenone 9}

To a solution of 2,4-dihydroxyacetophenone $(1.00 \mathrm{~g}, 6.57 \mathrm{mmol})$ and potassium carbonate $(2.73 \mathrm{~g}, 19.72 \mathrm{mmol})$ in anhydrous acetone $(20 \mathrm{~mL})$, chloromethyl methyl ether $(0.749 \mathrm{~mL}, 9.86 \mathrm{mmol})$ was added and the mixture refluxed for $1 \mathrm{~h}$ at $60^{\circ} \mathrm{C}$. Then, the reaction 
mixture was filtered, evaporated under reduced pressure and purified by flash column chromatography $\left(\mathrm{SiO}_{2} ; \mathrm{n}\right.$-hexane: ethyl acetate, 9:1), giving rise to 9 with $84 \%$ yield. The structure elucidation of compound 9 was established by ${ }^{1} \mathrm{H}$ and ${ }^{13} \mathrm{C}$ NMR techniques and data were in accordance with previously reported results [55].

\subsubsection{Synthesis of Chalcones 10a and $\mathbf{1 0 b}$}

To a solution of $9(0.500 \mathrm{~g}, 2.55 \mathrm{mmol})$ in methanol $(20 \mathrm{~mL})$ a solution of $40 \%$ $\mathrm{NaOH}$ in methanol was added until $\mathrm{pH} 14$, under stirring. Then, a solution of 3,4dimethoxybenzaldehyde $(0.847 \mathrm{~g}, 5.10 \mathrm{mmol})$ or 3,4,5-trimethoxybenzaldehyde $(1.00 \mathrm{~g}$, $5.10 \mathrm{mmol}$ ) in methanol was slowly added to the reaction mixture. The reaction was submitted to MW irradiation at $180 \mathrm{~W}$ at $70{ }^{\circ} \mathrm{C}$ for $4 \mathrm{~h}$. Then, a solution of $10 \% \mathrm{HCl}$ was added until $\mathrm{pH} 5$, and the obtained solid was filtered and washed with water and purified by crystallization with methanol, giving rise to $10 \mathrm{a}$ and $10 \mathrm{~b}$ with $33 \%$ and $47 \%$ yield, respectively. The structure elucidation of both compounds was established by ${ }^{1} \mathrm{H}$ and ${ }^{13} \mathrm{C}$ NMR techniques and data of 10a were in accordance with previously reported results [24]. Although the synthesis of compound $10 \mathrm{~b}$ has been previously reported [25], the NMR data are described here for the first tim $€(E)$-1-(2-hydroxy-4-(methoxymethoxy)phenyl)-3(3,4,5-trimethoxyphenyl)prop-2-en-1-one (10b). Yellow solid; yield: 47\%; m.p.: $132-134{ }^{\circ} \mathrm{C}$ (methanol); ${ }^{1} \mathrm{H}$ NMR $\left(\mathrm{CDCl}_{3}, 500 \mathrm{MHz}\right), \delta: 13.29\left(1 \mathrm{H}, \mathrm{s}, \mathrm{OH}-2^{\prime}\right), 7.85(1 \mathrm{H}, \mathrm{d}, \mathrm{J}=9.1 \mathrm{~Hz}$, H-6 $\left.{ }^{\prime}\right), 7.81(1 \mathrm{H}, \mathrm{d}, \mathrm{J}=15.4 \mathrm{~Hz}, \mathrm{H}-\beta), 7.45(1 \mathrm{H}, \mathrm{d}, \mathrm{J}=15.4 \mathrm{~Hz}, \mathrm{H}-\alpha) 6.87(2 \mathrm{H}, \mathrm{s}, \mathrm{H}-2$ and $\mathrm{H}-6), 6.65\left(1 \mathrm{H}, \mathrm{d}, \mathrm{J}=2.4 \mathrm{~Hz}, \mathrm{H}-3^{\prime}\right), 6.60\left(1 \mathrm{H}, \mathrm{dd}, \mathrm{J}=9.0,2.5 \mathrm{~Hz}, \mathrm{H}-5^{\prime}\right), 5.23\left(2 \mathrm{H}, \mathrm{s}, \mathrm{H}-1^{\prime \prime}\right)$, $3.93\left(6 \mathrm{H}, \mathrm{s}, 3-\mathrm{OCH}_{3}\right.$ and $\left.5-\mathrm{OCH}_{3}\right), 3.91\left(3 \mathrm{H}, \mathrm{s}, 4-\mathrm{OCH}_{3}\right), 3.49\left(3 \mathrm{H}, \mathrm{s}, \mathrm{H}-2^{\prime \prime}\right) .{ }^{13} \mathrm{C} \mathrm{NMR}$ $\left(\mathrm{CDCl}_{3}, 120 \mathrm{MHz}\right) \delta: 192.0(\mathrm{CO}), 166.4\left(\mathrm{C}^{\prime}\right), 163.8\left(\mathrm{C}^{\prime}\right), 153.6(\mathrm{C} 3$ and $\mathrm{C} 5), 144.9(\mathrm{C} \beta)$, $140.7(\mathrm{C} 4), 131.4\left(\mathrm{C}^{\prime}\right), 130.4(\mathrm{C} 1), 119.5(\mathrm{C} \alpha), 115.0\left(\mathrm{C1}^{\prime}\right), 108.4\left(\mathrm{C}^{\prime}\right), 105.9(\mathrm{C} 2$ and $\mathrm{C} 6)$, $104.1\left(\mathrm{C}^{\prime}\right), 94.2\left(\mathrm{Cl}^{\prime \prime}\right), 61.2\left(4-\mathrm{OCH}_{3}\right), 56.6\left(\mathrm{C}^{\prime \prime}\right), 56.4\left(3-\mathrm{OCH}_{3}\right.$ and $\left.5-\mathrm{OCH}_{3}\right)$.

\subsubsection{Synthesis of Chalcones 11a and 11b}

To a solution of $10 \mathrm{a}(0.200 \mathrm{~g}, 0.58 \mathrm{mmol})$ or $10 \mathrm{~b}(0.250 \mathrm{~g}, 0.67 \mathrm{mmol})$ in methanol $(10 \mathrm{~mL})$, p-toluenesulfonic acid monohydrate $(0.110 \mathrm{~g}, 0.58 \mathrm{mmol}$ or $0.127 \mathrm{~g}, 0.67 \mathrm{mmol})$ was added. The reaction was submitted to conventional heating at $50{ }^{\circ} \mathrm{C}$ for $5 \mathrm{~h}$. After the addiction of $10 \mathrm{~mL}$ of water, methanol was evaporated, and the aqueous solution was extracted with ethyl acetate $(2 \times 20 \mathrm{~mL})$. The organic phase was washed with water $(1 \times 20 \mathrm{~mL})$, dried over anhydrous sodium sulphate and concentrated under reduced pressure, giving rise to an orange solid. The crude product was purified by flash column chromatography (n-hexane: ethyl acetate, 8:2) (11a) or crystallization with chloroform (11b), giving rise to chalcone $11 \mathrm{a}$ and $\mathbf{1 1 b}$ with $24 \%$ and $31 \%$ yield, respectively. The structure elucidation of compounds 11a and $\mathbf{1 1 b}$ was established by ${ }^{1} \mathrm{H}$ and ${ }^{13} \mathrm{C}$ NMR techniques and data were in accordance with previously reported results [56,57].

\subsubsection{Synthesis of 2,3,4,6-Tetra-O-Acetyl- $\beta$-D-Glucopyranosyl Azide (12)}

To a solution of 2,3,4,6-tetra-O-acetyl- $\alpha$-D-glucopyranosyl bromide (1.00 g, $2.43 \mathrm{mmol})$ in acetone: water $(9 \mathrm{~mL}, 2: 1)$, sodium azide $(0.197 \mathrm{~g}, 3.04 \mathrm{mmol})$ was added and the reaction mixture stirred at room temperature for $3 \mathrm{~h}$. After, the acetone was evaporated under reduced pressure and a white solid was filtered. Crystallization of the solid with ethanol afforded 2,3,4,6-tetra-O-acetyl- $\alpha$-D-glucopyranosyl azide 12 with $72 \%$ yield. The structure elucidation was established by ${ }^{1} \mathrm{H}$ and ${ }^{13} \mathrm{C}$ NMR techniques and data were in accordance with previously reported results [27].

\subsection{Mussel (Mytilus galloprovincialis) Larvae Anti-Settlement Activity}

Mussel (Mytilus galloprovincialis) plantigrades were collected in juvenile aggregates during low neap tides at Memória beach, Matosinhos, Portugal $\left(41^{\circ} 13^{\prime} 59^{\prime \prime} \mathrm{N} ; 8^{\circ} 43^{\prime} 28^{\prime \prime} \mathrm{W}\right)$. In laboratory, mussel plantigrade larvae $(0.5-2 \mathrm{~mm})$ were isolated in a binocular magnifier (Olympus SZX2-ILLT, Tokyo, Japan) to a petri dish with filtered seawater, and those with functional foot and competent exploring behaviour were selected for the bioassays. 
The flavonoids were screened at $50 \mu \mathrm{M}$ in 24-well microplates with 4 well replicates per condition and 5 larvae per well, for $15 \mathrm{~h}$, in the darkness at $18 \pm 1{ }^{\circ} \mathrm{C}$, following Almeida et al. (2015) [58]. Test solutions were obtained by dilution of the compounds stock solutions $(50 \mathrm{mM})$ in DMSO and prepared with filtered seawater. All bioassays included a negative control with DMSO and a positive control with $\mathrm{CuSO}_{4}$, a potent $\mathrm{AF}$ agent. After the exposure period, the anti-settlement activity was determined by the presence/absence of attached byssal threads produced by each individual larvae.

All compounds that caused more than $60 \%$ of settlement inhibition ( $\leq 40 \%$ of settlement) in the screening bioassay were considered active and selected for the determination of the semi-maximum response concentration that inhibited $50 \%$ of larval settlement $\left(\mathrm{EC}_{50}\right)$, at compounds concentrations of $3.12,6.25,12.5,25,50,100,200 \mu \mathrm{M}$.

\subsection{Quantitative Structure-Activity Relationship}

The eighteen flavonoid derivatives $(\mathbf{1} \mathbf{a}, \mathbf{1} \mathbf{b}, \mathbf{2} \mathbf{a}, \mathbf{2} \mathbf{b}, \mathbf{3 a}, \mathbf{3} \mathbf{b}, \mathbf{4} \mathbf{a}, \mathbf{4} \mathbf{b}$ from Scheme $1 ; \mathbf{6} \mathbf{a}$, $\mathbf{6 b}, \mathbf{7 a}, 7 \mathbf{b}, \mathbf{8 a}, \mathbf{8 b}$ from Scheme 2; and 10a, 10b, 11a, 11b from Scheme 3) were used to build a QSAR model using the experimental data obtained from the mussel (Mytilus galloprovincialis) larvae anti-settlement activity in vivo bioassay (AF activity $=\log (100 / \%$ settlement). AF activity was selected as a dependent variable in the QSAR analysis. The 18 molecules were randomly distributed into a training set ( 15 molecules) and a test set (3 molecules). CODESSA software (version 2.7.10, University of Florida, Gainesville, FL, USA) was used to calculate more than 500 constitutional, topological, geometrical, electrostatic, quantum-chemical and thermodynamical molecular descriptors [59]. The heuristic multilinear regression methodology was chosen to perform a complete search for the best multilinear correlations with a multitude of descriptors of the training set [60]. The 2D-QSAR model with the best square of the correlation coefficient $\left(\mathrm{R}^{2}\right)$, F-test $(\mathrm{F})$, and squared standard error $\left(\mathrm{S}^{2}\right)$ was selected. The final model was further validated using the test set and leave-one-out (LOO) internal validation.

\subsection{Inhibitory Activity against Biofilm-Forming Marine Bacteria Growth}

For anti-bacterial screening, five strains of marine biofilm-forming bacteria from the Spanish Type Culture Collection (CECT): Cobetia marina CECT 4278, Vibrio harveyi CECT 525, Halomonas aquamarina CECT 5000, Pseudoalteromonas atlantica CECT 570, and Roseobacter litoralis CECT 5395 were used. Bacteria were inoculated and incubated for $24 \mathrm{~h}$ at $26^{\circ} \mathrm{C}$ in marine broth (Difco) at an initial density of 0.1 (OD600) in 96 well flat-bottom microtiter plates and exposed to the test compounds at $15 \mu \mathrm{M}$. Test solutions were obtained by dilution of the compounds stock solutions ( $50 \mathrm{mM}$ ) in DMSO. Bacterial growth inhibition in the presence of the compounds was determined in quadruplicate at $600 \mathrm{~nm}$ using a microplate reader (Biotek Synergy HT, Vermont, USA). Negative and positive controls used were a solution of marine broth with DMSO, and a solution of marine broth with penicillin-streptomycin-neomycin, respectively. Compounds exerting a significant antibacterial activity (Dunnet test, $p<0.05$ ) in the screening bioassays were selected for the determination of the effective inhibitory concentration $\left(\mathrm{EC}_{50}\right)$.

\subsection{Inhibitory Activity against Biofilm-Forming Marine Diatom Growth}

The anti-microalgal activity of the most promising compounds was also evaluated against a benthic marine diatom, Navicula sp., purchased from the (Telde, Gran Canaria) Spanish Collection of Algae (BEA). Diatom cells were inoculated in $\mathrm{f} / 2$ medium (Sigma) at an initial concentration of 2-4 $\times 106$ cells $\mathrm{mL}^{-1}$ and grown in 96-well flat-bottom microtiter plates for 10 days at $20^{\circ} \mathrm{C}$. Navicula growth inhibition in the presence of each compound at $15 \mu \mathrm{M}$ was determined in quadruplicate and quantified based on the difference in cell densities among the treatments, and cells were counted using a Neubauer counting chamber. A positive control with cycloheximide $(3.55 \mu \mathrm{M})$ and a negative control with $\mathrm{f} / 2$ medium $0.1 \%$ DMSO were included. Compounds that showed significant inhibitory 
activity in the screening assay (Dunnet test, $p<0.05$ ) were selected for further determination of their effective inhibitory concentrations $\left(\mathrm{EC}_{50}\right)$.

\subsection{In Vitro Acetylcholinesterase (AChE) and Tyrosinase (Tyr) Activities}

The ability of the most promising compounds to inhibit AChE and Tyr was tested to assess their potential mode of action related with neurotransmission disruption or impairment of adhesive metabolism pathways, respectively.

AChE activity was evaluated using Electrophorus electric AChE Type V-S (SIGMA C2888, E.C. 3.1.1.7), according to Ellman et al. (1961) [61] with some modifications [58,62]. Reaction solution containing $1 \mathrm{M}$ phosphate buffer $\mathrm{pH} 7.2,10 \mathrm{mM}$ dithiobisnitrobenzoate (DTNB) (acid dithiobisnitrobenzoate and sodium hydrogen carbonate in phosphate buffer) and $0.075 \mathrm{M}$ acetylcholine iodide was added to pure AChE enzyme $(0.25 \mathrm{U} / \mathrm{mL})$ and each test compound (final concentration of 25, 50 and $100 \mu \mathrm{M}, 1 \% \mathrm{DMSO}$ ) in quadruplicate. All tests included a positive control with eserine $(200 \mu \mathrm{M}$, water $)$ and a negative control with $1 \%$ DMSO in water. The optical density was measured at $412 \mathrm{~nm}$ in a microplate reader (Biotek Synergy HT, Winooski, Vermont, USA) during $5 \mathrm{~min}$ at $25^{\circ} \mathrm{C}$.

Tyr inhibition assay was performed using Agaricus bisporus Tyr (EC1.14.18.1) according to Adhikari et al. (2008) [63] with some modifications [8]. The enzymatic reaction follows the catalytic conversion of L-Dopa to dopaquinone and the formation of dopachrome by measuring the absorbance at $475 \mathrm{~nm}$. Briefly, Tyr $(25 \mathrm{U} / \mathrm{mL})$ was added to $50 \mathrm{mM}$ phosphate buffer $\mathrm{pH} 6.5$ and the tested compounds at 25, 50 and $100 \mu \mathrm{M}$ (final concentrations, $1 \%$ DMSO). The enzymatic activity was triggered by the addition of L-dopa (25 $\mathrm{mM})$. Kojic acid (1.4 mM, water) was included as positive control and 1\% DMSO in water as negative control.

\subsection{Environmental Fate Parameters: Artemia Salina Ecotoxicity Bioassay}

The brine shrimp (Artemia salina) nauplii lethality test was used to determine the toxicity of promising AF compounds to non-target organisms [64]. Artemia salina eggs were allowed to hatch in seawater for $48 \mathrm{~h}$ at $25^{\circ} \mathrm{C}$. Bioassays were performed in 96-wells microplates with 15-20 nauplii per well and $200 \mu \mathrm{L}$ of the compounds test solution. Compounds were tested at final concentrations of 25 and $50 \mu \mathrm{M}$ (filtered seawater with $1 \%$ DMSO). All tests included $\mathrm{K}_{2} \mathrm{Cr}_{2} \mathrm{O}_{7}(13.6 \mu \mathrm{M})$ as positive control and DMSO $(1 \%)$ as negative control. Bioassays were run in the dark at $25^{\circ} \mathrm{C}$, and the percentage of mortality was determined after $48 \mathrm{~h}$ of exposure.

\subsection{Statistical Analysis}

Datasets from anti-settlement, antibacterial and anti-microalgal bioassay, and determination of AChE and Tyr activities, were analysed by one-way analysis of variance (ANOVA) followed by a multi-comparisons Dunnett's test against negative control $(p<0.05)$. For the AF bioassays, the half maximum response concentration $\left(\mathrm{EC}_{50}\right)$ values for each compound, when applicable, were calculated using Probit regression analysis. Significance was considered at $p<0.01$, and 95\% lower and upper confidence limits (95\%LCL; UCL). The software IBM SPSS Statistics 26 (Armonk, New York, USA) was used for statistical analysis.

\section{Conclusions}

In this study, eight new triazole-flavonoid hybrids were synthesized using the click chemistry approach. From the series of synthesized compounds, flavone $\mathbf{1 b}$ and chalcones 7b, 11a and 11b showed significant anti-settlement activity towards the macrofouling species Mytilus galloprovincialis adhesive larvae. Regarding the compounds' structures, HACA1 was the most significant descriptor for the obtained QSAR model, contributing positively to the AF activity. Particularly, triazolyl glycosylated chalcone $\mathbf{7 b}$, with a high number of hydrogen-bonding acceptors, showed the most effective anti-settlement activity $\left(\mathrm{EC}_{50}=3.28 \mu \mathrm{M} ; 2.43 \mu \mathrm{g} \cdot \mathrm{mL}^{-1}\right)$ with the highest therapeutic ratio $\left(\mathrm{LC}_{50} / \mathrm{EC}_{50}>60.98\right)$, exhibiting also a significant inhibitory activity against the marine diatom Navicula sp. 
$\left(\mathrm{EC}_{50}=41.76 \mu \mathrm{M} ; 30.94 \mu \mathrm{g} \cdot \mathrm{mL}^{-1}\right)$, suggesting potential in the suppression of biofouling colonization succession. Flavone $\mathbf{1 b}$, which was effective against the settlement of mussel larvae, also showed capacity to inhibit the activity of Tyr, which might explain the specific AF activity against mussel larvae. Ecotoxicity studies on the non-target species Artemia salina revealed that the flavonoids $\mathbf{1} \mathbf{b}, \mathbf{7 b}, \mathbf{1 1} \mathbf{a}$ and $\mathbf{1 1} \mathbf{b}$ did not show ecotoxicity to the nauplii of this sensitive crustacean, even at $50 \mu \mathrm{M}$, a concentration much higher than their $\mathrm{EC}_{50}$. These results disclosed synthetic flavonoids, particularly a new chalcone incorporating a 1,2,3- triazole ring ( $7 \mathbf{b})$, with potential to be a good environmentally compatible alternative to the majority of the antifoulants in use. Flavonoids are ubiquitous in Nature and, therefore, they come with the advantage that they have been selected during evolution to have high specificity, high efficiency and some might be potential nontoxic inhibitors of fouling. Natural compounds are usually biodegradable, not leaving residue in the environment, and are thus considered one of the most promising alternatives to the biocides in use. However, the yields of natural compounds from marine organisms are generally poor, hindering their development as AF agents. Moreover, optimizing a micro-organism for enhanced production of antifoulant is generally laborious and time consuming. Synthesis of nature-like antifoulants seems to be a more sustainable way to create an opportunity to produce commercial supplies for the antifouling industry.

Author Contributions: Conceptualization, H.C.; methodology, J.R.A.; M.C.-d.-S.; and H.C.; compounds synthesis, D.P.; B.T.M.; compounds structure elucidation, D.P.; quantitative structureactivity relationship studies, A.P.; in vivo AF bioassays, enzymatic determinations and ecotoxicological bioassays, C.G.; J.R.A.; resources, M.P.; V.V.; writing—original draft preparation, D.P.; C.G.; writing-review and editing, D.P.; C.G.; J.R.A.; M.C.-d.-S.; H.C.; M.P.; V.V.; supervision, J.R.A.; M.C.-d.-S.; H.C.; project administration, J.R.A. and M.C.-d.-S.; funding acquisition, V.V., J.R.A. and M.C.-d.-S. All authors have read and agreed to the published version of the manuscript.

Funding: This research was supported by national funds through the FCT-Foundation for Science and Technology within the scope of UIDB/04423/2020 and UIDP/04423/2020 and under the projects: NASCEM-PTDC/BTA-BTA/31422/2017 (POCI-01-0145-FEDER-031422), and PTDC/AAGTEC/0739/2014 (POCI-01-0145-FEDER-016793; Project 9471-RIDTI) co-financed by FCT, PORTUGAL2020 COMPETE 2020, through the European Regional Development Fund (ERDF); and by the structured program of R\&D\&I ATLANTIDA (reference NORTE-01-0145-FEDER-000040), supported by the North Portugal Regional Operational Programme (NORTE2020), through the ERDF. D. P. and C. G. acknowledge the grants they received (SFRH/BD/147207/2019 and NASCEM/BILic/2019-53, respectively).

Institutional Review Board Statement: Not applicable.

Informed Consent Statement: Not applicable.

Data Availability Statement: Data is contained within the article.

Acknowledgments: The authors thank Sara Cravo for all the technical and scientific support.

Conflicts of Interest: The authors declare no conflict of interest.

\section{References}

1. Amara, I.; Miled, W.; Slama, R.B.; Ladhari, N. Antifouling processes and toxicity effects of antifouling paints on marine environment. A review. Environ. Toxicol. Pharmacol. 2018, 57, 115-130. [CrossRef] [PubMed]

2. Wang, K.-L.; Wu, Z.-H.; Wang, Y.; Wang, C.-Y.; Xu, Y. Mini-Review: Antifouling Natural Products from Marine Microorganisms and Their Synthetic Analogs. Mar. Drugs 2017, 15, 266. [CrossRef] [PubMed]

3. Dubalska, K.; Rutkowska, M.; Bajger-Nowak, G.; Konieczka, P.; Namieśnik, J. Organotin Compounds: Environmental Fate and Analytics. Crit. Rev. Anal. Chem. 2013, 43, 35-54. [CrossRef]

4. Bao, V.W.W.; Leung, K.M.Y.; Lui, G.C.S.; Lam, M.H.W. Acute and chronic toxicities of Irgarol alone and in combination with copper to the marine copepod Tigriopus japonicus. Chemosphere 2013, 90, 1140-1148. [CrossRef]

5. Kyei, S.K.; Darko, G.; Akaranta, O. Chemistry and application of emerging ecofriendly antifouling paints: A review. J. Coat. Technol. Res. 2020, 17, 315-332. [CrossRef]

6. Rossini, P.; Napolano, L.; Matteucci, G. Biotoxicity and life cycle assessment of two commercial antifouling coatings in marine systems. Chemosphere 2019, 237, 124475. [CrossRef] 
7. Martins, B.T.; Correia da Silva, M.; Pinto, M.; Cidade, H.; Kijjoa, A. Marine natural flavonoids: Chemistry and biological activities. Nat. Prod. Res. 2019, 33, 3260-3272. [CrossRef]

8. Almeida, J.R.; Correia-da-Silva, M.; Sousa, E.; Antunes, J.; Pinto, M.; Vasconcelos, V.; Cunha, I. Antifouling potential of Natureinspired sulfated compounds. Sci. Rep. 2017, 7, 42424. [CrossRef]

9. Almeida, J.R.; Moreira, J.; Pereira, D.; Pereira, S.; Antunes, J.; Palmeira, A.; Vasconcelos, V.; Pinto, M.; Correia-da-Silva, M.; Cidade, H. Potential of synthetic chalcone derivatives to prevent marine biofouling. Sci. Total Environ. 2018, 643, 98-106. [CrossRef]

10. Trojer, M.A.; Movahedi, A.; Blanck, H.; Nydén, M. Imidazole and Triazole Coordination Chemistry for Antifouling Coatings. J. Chem. 2013, 2013, 23.

11. Hou, J.; Liu, X.; Shen, J.; Zhao, G.; Wang, P.G. The impact of click chemistry in medicinal chemistry. Expert Opin. Drug Discov. 2012, 7, 489-501. [CrossRef] [PubMed]

12. Totobenazara, J.; Burke, A.J. New click-chemistry methods for 1,2,3-triazoles synthesis: Recent advances and applications. Tetrahedron Lett. 2015, 56, 2853-2859. [CrossRef]

13. Agalave, S.G.; Maujan, S.R.; Pore, V.S. Click chemistry: 1,2,3-triazoles as pharmacophores. Chem Asian J. 2011, 6, 2696-2718 [CrossRef] [PubMed]

14. Kolb, H.C.; Sharpless, K.B. The growing impact of click chemistry on drug discovery. Drug Discov. Today 2003, 8, 1128-1137. [CrossRef]

15. Ma, N.; Wang, Y.; Zhao, B.X.; Ye, W.C.; Jiang, S. The application of click chemistry in the synthesis of agents with anticancer activity. Drug Des. Devel Ther. 2015, 9, 1585-1599.

16. Tron, G.C.; Pirali, T.; Billington, R.A.; Canonico, P.L.; Sorba, G.; Genazzani, A.A. Click chemistry reactions in medicinal chemistry: Applications of the 1,3-dipolar cycloaddition between azides and alkynes. Med. Res. Rev. 2008, 28, 278-308. [CrossRef]

17. Andjouh, S.; Blache, Y. Screening of bromotyramine analogues as antifouling compounds against marine bacteria. Biofouling 2016, 32, 871-881. [CrossRef]

18. Kantheti, S.; Narayan, R.; Raju, K.V.S.N. The impact of 1,2,3-triazoles in the design of functional coatings. RSC Adv. 2015, 5, 3687-3708. [CrossRef]

19. Seijas, J.A.; Vazquez-Tato, M.P.; Carballido-Reboredo, R. Solvent-free synthesis of functionalized flavones under microwave irradiation. J. Org. Chem 2005, 70, 2855-2858. [CrossRef]

20. Rostovtsev, V.V.; Green, L.G.; Fokin, V.V.; Sharpless, K.B. A stepwise huisgen cycloaddition process: Copper(I)-catalyzed regioselective "ligation" of azides and terminal alkynes. Angew. Chem. Int. Ed. 2002, 41, 2596-2599. [CrossRef]

21. Tornøe, C.W.; Christensen, C.; Meldal, M. Peptidotriazoles on solid phase: [1,2,3]-Triazoles by regiospecific copper(I)-catalyzed 1,3-dipolar cycloadditions of terminal alkynes to azides. J. Org. Chem. 2002, 67, 3057-3064. [CrossRef] [PubMed]

22. Liang, L.; Astruc, D. The copper(I)-catalyzed alkyne-azide cycloaddition (CuAAC) "click" reaction and its applications. An overview. Coord Chem Rev. 2011, 255, 2933-2945. [CrossRef]

23. Zhao, L.; Mao, L.; Hong, G.; Yang, X.; Liu, T. Design, synthesis and anticancer activity of matrine-1H-1,2,3-triazole-chalcone conjugates. Bioorg. Med. Chem. Lett. 2015, 25, 2540-2544. [CrossRef] [PubMed]

24. Park, J.; Khloya, P.; Seo, Y.; Kumar, S.; Lee, H.K.; Jeon, D.-K.; Jo, S.; Sharma, P.K.; Namkung, W. Potentiation of $\Delta$ F508- and G551D-CFTR-Mediated Cl- Current by Novel Hydroxypyrazolines. PLoS ONE 2016, 11, e0149131. [CrossRef]

25. Zhang, J.; Fu, X.L.; Yang, N.; Wang, Q.A. Synthesis and cytotoxicity of chalcones and 5-deoxyflavonoids. Sci. World J. 2013, 2013. [CrossRef]

26. Loureiro, D.R.P.; Magalhães, Á.F.; Soares, J.X.; Pinto, J.; Azevedo, C.M.G.; Vieira, S.; Henriques, A.; Ferreira, H.; Neves, N.; Bousbaa, H.; et al. Yicathins B and C and Analogues: Total Synthesis, Lipophilicity and Biological Activities. ChemMedChem 2020, 15, 749-755. [CrossRef]

27. Adesoye, O.G.; Mills, I.N.; Temelkoff, D.P.; Jackson, J.A.; Norris, P. Synthesis of a d-Glucopyranosyl Azide: Spectroscopic Evidence for Stereochemical Inversion in the SN2 Reaction. J. Chem. Educ. 2012, 89, 943-945. [CrossRef]

28. Briand, J.F. Marine antifouling laboratory bioassays: An overview of their diversity. Biofouling 2009, 25, 297-311. [CrossRef]

29. Kojima, R.; Kobayashi, S.; Satuito, C.G.P.; Katsuyama, I.; Ando, H.; Seki, Y.; Senda, T. A Method for Evaluating the Efficacy of Antifouling Paints Using Mytilus galloprovincialis in the Laboratory in a Flow-Through System. PLoS ONE 2016, 11, e0168172. [CrossRef]

30. Aldred, N.; Ista, L.K.; Callow, M.E.; Callow, J.A.; Lopez, G.P.; Clare, A.S. Mussel (Mytilus edulis) byssus deposition in response to variations in surface wettability. J. $R$ Soc. Interface 2006, 3, 37-43. [CrossRef]

31. Qian, P.Y.; Xu, Y.; Fusetani, N. Natural products as antifouling compounds: Recent progress and future perspectives. Biofouling 2010, 26, 223-234. [CrossRef] [PubMed]

32. Dudek, A.Z.; Arodz, T.; Gálvez, J. Computational methods in developing quantitative structure-activity relationships (QSAR): A review. Comb. Chem. High. Throughput Screen. 2006, 9, 213-228. [CrossRef] [PubMed]

33. Dunn, W.J.; Hopfinger, A.J. 3D QSAR of Flexible Molecules Using Tensor Representation; Kluwer Academic Publishers: NewYork, NY, USA, 2002; Volume 3.

34. Kubinyi, H. QSAR: Hansch Analysis and Related Approaches; Wiley-VCH: Weinhem, Germany, $1993 ;$ Volume 1.

35. Veerasamy, R.; Rajak, H.; Jain, A.; Sivadasan, S.; Christapher, P.V.; Agrawal, R. Validation of QSAR Models-Strategies and Importance. Int. J. Drug Design Discov. 2011, 2, 511-519.

36. Alexander, D.L.J.; Tropsha, A.; Winkler, D.A. Beware of R(2): Simple, Unambiguous Assessment of the Prediction Accuracy of QSAR and QSPR Models. J. Chem. Inf. Model. 2015, 55, 1316-1322. [CrossRef] [PubMed] 
37. Liu, P.; Long, W. Current Mathematical Methods Used in QSAR/QSPR Studies. Int. J. Mol. Sci. 2009, 10, 1978-1998. [CrossRef] [PubMed]

38. Gramatica, P. On the Development and Validation of QSAR Models. In Computational Toxicology: Volume II; Reisfeld, B., Mayeno, A.N., Eds.; Humana Press: Totowa, NJ, USA, 2013; pp. 499-526.

39. Golbraikh, A.; Shen, M.; Xiao, Z.; Xiao, Y.-D.; Lee, K.-H.; Tropsha, A. Rational selection of training and test sets for the development of validated QSAR models. J. Comput.-Aided Mol. Des. 2003, 17, 241-253. [CrossRef]

40. OECD. Guidance Document on the Validation of (Quantitative) Structure-Activity Relationships [(Q)SAR] Models; OECD: Paris, France, 2007.

41. Todeschini, R.; Consonni, V. Molecular Descriptors for Chemoinformatics; Wiley-VCH: Weinheim, Germany, 2009; Volume I.

42. Dunn, W.J. Handbook of Molecular Descriptors. Methods and Principles in Medicinal Chemistry Series. Volume 11 By Roberto Todeschini and Viviana Consonni (Universita degli Studi di Milano-Bicocca). Edited by R. Mannold, H. Kubinyi, and H. Timmerman. Wiley-VCH: Weinheim and New York. 2000. xxi + 668 pp. 498 DM. ISBN 3-527-29913-O. J. Am. Chem. Soc. 2001, $123,7198$.

43. Roy, K.; Kar, S.; Das, R.N. Understanding the Basics of QSAR for Applications in Pharmaceutical Sciences and Risk Assessment; Academic Press: Boston, MA, USA, 2015.

44. Almeida, J.R.; Vasconcelos, V. Natural antifouling compounds: Effectiveness in preventing invertebrate settlement and adhesion. Biotechnol. Adv. 2015, 33, 343-357. [CrossRef]

45. Qian, P.Y.; Chen, L.; Xu, Y. Mini-review: Molecular mechanisms of antifouling compounds. Biofouling 2013, 29, 381-400. [CrossRef]

46. Chen, L.; Qian, P.Y. Review on Molecular Mechanisms of Antifouling Compounds: An Update since 2012. Mar. Drugs 2017, 15, 264. [CrossRef]

47. Chen, L.; Au, D.W.; Hu, C.; Peterson, D.R.; Zhou, B.; Qian, P.Y. Identification of Molecular Targets for 4,5-Dichloro-2-n-octyl4-isothiazolin-3-one (DCOIT) in Teleosts: New Insight into Mechanism of Toxicity. Environ. Sci. Technol. 2017, 51, 1840-1847. [CrossRef] [PubMed]

48. Chen, L.; Zhang, H.; Sun, J.; Wong, Y.H.; Han, Z.; Au, D.W.; Bajic, V.B.; Qian, P.Y. Proteomic changes in brain tissues of marine medaka (Oryzias melastigma) after chronic exposure to two antifouling compounds: Butenolide and 4,5-dichloro-2-n-octyl-4isothiazolin-3-one (DCOIT). Aquat. Toxicol. (Amst. Neth.) 2014, 157, 47-56. [CrossRef] [PubMed]

49. Nong, X.H.; Wang, Y.F.; Zhang, X.Y.; Zhou, M.P.; Xu, X.Y.; Qi, S.H. Territrem and butyrolactone derivatives from a marine-derived fungus Aspergillus terreus. Mar. Drugs 2014, 12, 6113-6124. [CrossRef] [PubMed]

50. Tadesse, M.; Svenson, J.; Sepcic, K.; Trembleau, L.; Engqvist, M.; Andersen, J.H.; Jaspars, M.; Stensvag, K.; Haug, T. Isolation and synthesis of pulmonarins A and B, acetylcholinesterase inhibitors from the colonial ascidian Synoicum pulmonaria. J. Nat. Prod. 2014, 77, 364-369. [CrossRef] [PubMed]

51. Jiang, W.; Duysen, E.G.; Lockridge, O. Induction of plasma acetylcholinesterase activity and apoptosis in mice treated with the organophosphorus toxicant, tri-o-cresyl phosphate. Toxicol. Res. 2012, 1, 55-61. [CrossRef]

52. Martin-Rodriguez, A.J.; Babarro, J.M.; Lahoz, F.; Sanson, M.; Martin, V.S.; Norte, M.; Fernandez, J.J. From broad-spectrum biocides to quorum sensing disruptors and mussel repellents: Antifouling profile of alkyl triphenylphosphonium salts. PLoS ONE 2015, 10, e0123652. [CrossRef]

53. Katranitsas, A.; Castritsi-Catharios, J.; Persoone, G. The effects of a copper-based antifouling paint on mortality and enzymatic activity of a non-target marine organism. Mar. Pollut. Bull. 2003, 46, 1491-1494. [CrossRef]

54. Koutsaftis, A.; Aoyama, I. Toxicity of four antifouling biocides and their mixtures on the brine shrimp Artemia salina. Sci. Total Environ. 2007, 387, 166-174. [CrossRef]

55. Sugamoto, K.; Matsusita, Y.-i.; Matsui, K.; Kurogi, C.; Matsui, T. Synthesis and antibacterial activity of chalcones bearing prenyl or geranyl groups from Angelica keiskei. Tetrahedron 2011, 67, 5346-5359. [CrossRef]

56. Lim, S.S.; Jung, S.H.; Ji, J.; Shin, K.H.; Keum, S.R. Synthesis of flavonoids and their effects on aldose reductase and sorbitol accumulation in streptozotocin-induced diabetic rat tissues. J. Pharm. Pharmacol. 2001, 53, 653-668. [CrossRef]

57. Neves, M.P.; Cravo, S.; Lima, R.T.; Vasconcelos, M.H.; Nascimento, M.S.J.; Silva, A.M.S.; Pinto, M.; Cidade, H.; Corrêa, A.G. Solid-phase synthesis of 2'-hydroxychalcones. Effects on cell growth inhibition, cell cycle and apoptosis of human tumor cell lines. Bioorg. Med. Chem. 2012, 20, 25-33. [CrossRef] [PubMed]

58. Almeida, J.R.; Freitas, M.; Cruz, S.; Leão, P.N.; Vasconcelos, V.; Cunha, I. Acetylcholinesterase in Biofouling Species: Characterization and Mode of Action of Cyanobacteria-Derived Antifouling Agents. Toxins 2015, 7, 2739-2756. [CrossRef] [PubMed]

59. Katritsky, A.; Karelson, M.; Lobanov, V.S.; Dennington, R.; Keith, T. CODESSA 2.7.10; Semichem, Inc.: Shawnee, KS, USA, 2004.

60. Ćwik, J.; Koronacki, J. A Heuristic Method of Model Choice for Nonlinear Regression. In Proceedings of the Rough Sets and Current Trends in Computing, Berlin, Heidelberg, 22-26 June 1998; pp. 68-74.

61. Ellman, G.L.; Courtney, K.D.; Andres, V.; Featherstone, R.M. A new and rapid colorimetric determination of acetylcholinesterase activity. Biochem. Pharmacol. 1961, 7, 88-95. [CrossRef]

62. Cunha, I.; Garcia, L.M.; Guilhermino, L. Sea-urchin (Paracentrotus lividus) glutathione S-transferases and cholinesterase activities as biomarkers of environmental contamination. J. Environ. Monit 2005, 7, 288-294. [CrossRef]

63. Adhikari, A.; Devkota, H.P.; Takano, A.; Masuda, K.; Nakane, T.; Basnet, P.; Skalko-Basnet, N. Screening of Nepalese crude drugs traditionally used to treat hyperpigmentation: In vitro tyrosinase inhibition. Int. J. Cosmet. Sci. 2008, 30, 353-360. [CrossRef]

64. Meyer, B.N.; Ferrigni, N.R.; Putnam, J.E.; Jacobsen, L.B.; Nichols, D.E.; McLaughlin, J.L. Brine shrimp: A convenient general bioassay for active plant constituents. Planta Med. 1982, 45, 31-34. [CrossRef] 